Discussion Paper No. 18-039

Higher Taxes on Less Elastic Goods? Evidence from German Municipalities

Sebastian Blesse, Philipp Doerrenberg, and Anna Rauch

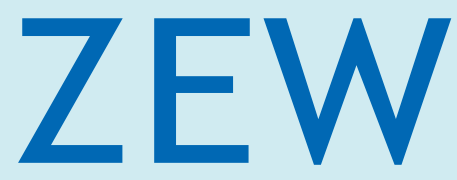

Zentrum für Europäische Wirtschaftsforschung $\mathrm{GmbH}$

Centre for European Economic Research 
Discussion Paper No. 18-039

\title{
Higher Taxes on Less Elastic Goods? Evidence from German Municipalities
}

\author{
Sebastian Blesse, Philipp Doerrenberg, \\ and Anna Rauch
}

Download this ZEW Discussion Paper from our ftp server:

http://ftp.zew.de/pub/zew-docs/dp/dp18039.pdf

Die Discussion Papers dienen einer möglichst schnellen Verbreitung von neueren Forschungsarbeiten des ZEW. Die Beiträge liegen in alleiniger Verantwortung der Autoren und stellen nicht notwendigerweise die Meinung des ZEW dar.

Discussion Papers are intended to make results of ZEW research promptly available to other economists in order to encourage discussion and suggestions for revisions. The authors are solely responsible for the contents which do not necessarily represent the opinion of the ZEW. 


\title{
Higher taxes on less elastic goods? Evidence from German municipalities*
}

\author{
Sebastian Blesse \\ PhILIPP DoERRENBERG
}

ANNA RAUCH

\begin{abstract}
Accepted for Publication in Regional Science and Urban Economics
\end{abstract}

\begin{abstract}
German municipalities have substantial autonomy in setting taxes on two distinct tax bases: business profits and property values. We use this setting and a two-step approach to explore whether implemented tax policy is consistent with the seminal inverse-elasticity rule. First, we estimate the tax elasticity of the two tax bases using event-study and generalized differences-in-differences methods based on the universe of municipalities in 1995-2010. Second, we compare the ratio of the observed tax rates for the two tax bases to the ratio of their estimated elasticities. We find that property is not very responsive to variation in tax rates, whereas business profits respond significantly. While this would suggest that property should be taxed at a higher rate, the data show that this not the case: most municipalities impose relatively higher rates on business profits. This suggests that municipality-level taxation in Germany is inconsistent with the inverse-elasticity rule. We provide suggestive evidence that this finding is explained by politician's imprecise expectations about revenue elasticities as well as re-election concerns.
\end{abstract}

JEL Classification: H2, H3, H7, R5

Keywords: Inverse-elasticity rule, Property taxes, Business taxes, Municipality-level taxation, Elasticity of Corporate Taxable Income

${ }^{*}$ Blesse: ZEW Mannheim. blesse@zew.de. Doerrenberg: ZEW Mannheim, CESifo and IZA. doerrenberg@zew.de. Rauch: contact details available upon request from the other authors. An earlier version of the paper circulated under the title "Does tax policy follow the inverseelasticity rule? Evidence from German municipalities". We are grateful to Felix Bierbrauer for very extensive guidance on this project. We further thank the editor (Yves Zenou), an anonymous referee, Denvil Duncan, Caroline Hummel, Max Loeffler, Andreas Peichl, Sebastian Siegloch, Michael Thoene, Johannes Voget, Alfons Weichenrieder and seminar participants at University Cologne, University of Mannheim, IZA Bonn and the Regional Economics Workshop in Dresden for valuable comments and suggestions. We thank Ozan Emre Akbas and Akin Mert for excellent research assistance as well as Eckhard Janeba for graciously sharing the survey data with us. Sebastian Blesse gratefully acknowledges support from the SFB 884 'The Political Economy of Reforms', which is funded by the German Research Foundation. The usual disclaimer applies. 


\section{Introduction}

The seminal contribution of Ramsey (1927) shows that optimal tax rates on goods depend inversely on their elasticity of demand. While the optimal-tax literature has made progress since Ramsey's initial contribution, the general idea of his framework has not lost ground: the excess burden of taxation is positively related to the sensitivity of the tax base, and the tax rate should be inversely related to a tax base's tax sensitivity. In the case of two tax bases, for example, Ramsey taxation suggests to impose a higher tax rate on the tax base that is relatively less responsive to taxrate changes. ${ }^{1}$ One important question that arises in this context is: do real-world policy makers apply the rules of Ramsey by imposing different tax rates on goods with different tax elasticities? In other words: does tax policy set higher tax rates on goods that are less responsive to taxation relative to more responsive goods?

Evidence on this question is scarce, and the reasons for this scarcity are twofold. First, in order to ensure comparability between the tax rates on different goods, one requires an institutional setting where tax rates on distinct taxable goods are set by the same institutional players and the taxed goods are subject to similar economic conditions. Second, since tax elasticities are to be estimated empirically, a setup is required that allows credible empirical identification of the tax sensitivity of the taxed goods of interest. In this paper, we address the research question in an empirical set-up that meets both requirements. We explore the unique case of local taxation on the municipal level in Germany, where more than 11,000 municipalities have autonomy to set taxes on business profits and property values. This empirical playground allows us to identify how changes in business and property taxes affect the respective tax revenues, ${ }^{2}$ and hence makes it possible to evaluate local taxation in Germany with respect to relative tax elasticities in the spirit of Ramsey. We particularly study whether different elasticities of the business-tax and property-tax

\footnotetext{
${ }^{1}$ Ramsey's original framework is about minimizing the deadweight loss of indirect taxes, and Diamond and Mirrlees (1971) show in an optimal-tax framework that production should not be distorted at all. However, the general rationale of Ramsey taxation yet also applies to other types of taxes. For example, the recent literature on the elasticity of taxable income (surveyed by Saez et al. 2012) concludes that optimal labor income taxes decrease with the mobility of the incometax base. In a similar vein, optimal corporate taxes depend on the mobility of the firm tax base (Kawano and Slemrod 2015; Devereux et al. 2014). Mankiw et al. (2009) and Piketty and Saez (2013) survey the current status of the optimal-tax literature.

${ }^{2}$ Note that there is a direct link between tax-revenue elasticities and tax-base elasticities: a high tax-revenue elasticity w.r.t. tax rates implies a low (in absolute terms) elasticity of the tax base w.r.t. taxes, and vice versa (see Section 4 for a detailed exposition of this rationale). We estimate the effect on tax revenues, rather than tax bases, because of data restrictions: the statistical offices do not provide long panel data on tax bases. Calculating the base as tax revenue divided by tax rate is not an option because of unobserved deductions and credits (Fossen and Steiner 2014) and because we do not have information on the distribution of property types in the municipalities.
} 
revenue, which we estimate empirically, translate into actual tax-policy following the inverse-elasticity rule (which is an advancement of the standard Ramsey result; see Baumol and Bradford 1970).

Our data set covers the full universe of German municipalities in a long panel of 16 years, 1995-2010. For identification, we rely on many (business and property) tax-rate reforms that were implemented by the municipalities, and use event studies and generalized Differences-in-Differences (DiD) regressions to estimate the effects. The long panel dimension, along with the fact that the municipalities operate in a very homogeneous economic environment, allows us to control for many confounding factors that present potential threats to common trend assumptions. As opposed to many other empirical tax studies, we do not have to deal with changes in the tax base definitions that often come along with tax reforms, because the tax base, as well as a basic tax rate, is defined on the federal level and municipalities only set a multiplier on the exogenous basic rate and base. ${ }^{3}$ We exploit within-municipality variation over time to study how elastically business-tax and property-tax revenues respond to tax changes. While our event studies establish flat pre-reform trends, we estimate the magnitude of the treatment effects in the DiD setting. ${ }^{4}$

The event studies show that trends in revenues are flat before tax reforms, lending credibility to our identification strategy. Using the DiD regressions to quantify the effects, we find that that business-tax revenue does not significantly increase in response to tax changes. Property-tax revenue, on the other hand, increases by $0.67 \%$ in response to a $1 \%$ increase in the tax rate. These results imply that the business-tax base responds strongly to tax-rate changes whereas the property-tax base is not tax sensitive. ${ }^{5}$ If tax policy was consistent with the inverse-elasticity rule, our estimates would suggest that tax rates are significantly higher on immobile property than on mobile business profits. However, this is not what we observe. In almost all years of our sample period, the share of municipalities with a higher business tax than property tax is considerably greater than $50 \%$. In addition, the average business-tax rate is greater than the average property-tax rate in all years of our sample period. Our results are robust to a vast set of sensitivity checks.

\footnotetext{
${ }^{3}$ Due to data-access limitations and the non-existence of the long panel dimension out of a single data source, these data have not been used extensively by researchers. Notable exceptions include Buettner (2003) on the sensitivity of the business tax base, Becker et al. (2012) on the effect of the local tax on the activity of multinational enterprises, Foremny and Riedel (2014) for the effect of elections on tax-rate changes, and Fuest et al. (2017) on the incidence of the local business tax on wages.

${ }^{4}$ Our identification strategy, including the source of variation for the business-tax reforms and reliance on event studies and generalized DiD, is similar to the recent study by Fuest et al. (2017). This paper shows the existence of flat pre trends and provides several additional checks to support the validity of the identification strategy.

${ }^{5}$ See Section 4 on the relationship between the tax-base elasticity and the tax-revenue elasticity.
} 
Among others, our elasticity estimates are not driven by municipalities with higher property-tax rates than business-tax rates: municipalities which impose higher rates on business profits than on property also face much more tax responsive business profits than property.

The inverse-elasticity rule depicts that goods should be taxed in inverse proportion to their price elasticities. ${ }^{6}$ We can combine this rule with our elasticity estimates and conduct back-of-the-envelope calculations to determine the optimal relation between the business and property tax rates. Given our elasticity estimates of 0.117 for business-tax (putting aside the non-significance of this coefficient for now) and 0.668 for property-tax revenues, such calculations yield that the property tax rate should, from an inverse-elasticity perspective, nearly be six times higher on average than the business tax rate. This is in contrast to actual rates; we observe that throughout our sample period the business-tax multiplier is on average 1.08 times higher than the property-tax multiplier. This suggests that German municipalities are not compliant with the inverse-elasticity rule and leaves questions about why local politicians deviate from it in practice. ${ }^{7}$

We use additional data sources to shed light on potential mechanisms that can rationalize our findings that local taxation is not in line with the inverse-elasticity rule. First, using a survey among local German politicians, we study beliefs of policy makers about revenue elasticities. The majority of respondents in this survey believes that an increase in business taxes will lead to (substantially) higher tax revenues. This is somewhat in contrast to our findings and indicates that a lack of knowledge about elasticities can explain why business is taxed relatively high. We find that political ideology is a driver of the beliefs about revenue elasticities. Second, we study if political economy arguments matter for tax-setting behavior. Using the municipality data coupled with information about local election dates, we show that the growth rate of both property and business tax rates is lower in years of elections. This effect of elections is more pronounced for property taxes than for business taxes, which is in line with the political-economy argument of maximizing votes because home owners represent a larger group of voters than (incorporated)

\footnotetext{
${ }^{6}$ The inverse-elasticity rule is about minimizing deadweight loss in the presence of an exogenous revenue requirement. Note that municipalities arguably do face such a revenue requirement. For example, they are obligated by the federal level to finance large parts of child care and social assistance to unemployed individuals. The inverse-elasticity rule is given by $\tau_{1} \eta_{1}=\tau_{2} \eta_{2}$, where $\tau$ and $\eta$ are the tax rates and base elasticities of the two goods. See Section 4 for a formal argument on the relationship between the tax-base and tax-revenue elasticity.

${ }^{7}$ It is important to note that we do not wish to suggest that our findings imply that local taxation in Germany is inefficient with respect to overall welfare. We do not know the social welfare function which politicians maximize (it could for example include distributional concerns). As a result, we cannot infer any conclusions about welfare from our results. We only intend to make statements about the consistency with the inverse-elasticity rule itself.
} 
business owners. Taken together, all this suggests that politicians use tax policy as an instrument to stay in office.

Our paper speaks and contributes to three strands of literature. First, we relate to a small literature that studies whether actual tax policy follows the requirements of optimal-taxation theory. ${ }^{8}$ For example, Saez (2001) develops an optimal income tax model that can be applied based on empirically estimated earnings elasticities. Numerical simulations show that the pattern of actual tax schedules is close to the U-shaped pattern of optimal tax rates that he derives based on his model. The optimal top marginal tax rate, however, is higher than the actual top rate in the US (Diamond and Saez 2011). Mankiw et al. (2009) discuss the extent to which the most important lessons from the optimal-tax literature are consistent with actual policies. They conclude that "tax policy has moved in the directions suggested by theory along a few dimensions, even though the recommendations of theory along these dimensions are not always definitive." (Mankiw et al. 2009, pages 147/148). For example, they argue that the observed trend towards flatter income-tax rates in OECD countries may suggest that tax-policy is affected by optimal-tax theory. The paper mostly reports cross-country trends in taxation and does not provide a test of optimal-tax rules based on empirically estimated elasticities. Creedy and Gemell (2015) build on empirical estimates of the elasticity of taxable income to show that, for many individuals actual income-tax rates in the US are well in line with optimal revenue-maximizing tax rates. As opposed to our paper, these few studies on the optimality of actually implemented taxes are mostly on the personal income tax. We provide some first evidence in this regard for other taxes.

Second, we contribute to the literature on the elasticity of the corporate tax base and the elasticity of tax revenues. While the literature acknowledges that firms respond to tax incentives and adjust to taxes along various different dimensions, ${ }^{9}$ only a few papers explicitly study the tax-sensitivity of the overall tax bases and tax revenues. One reason for scarce evidence presumably is that in most countries, corporate taxes are levied on the national or state level, which hinders the causal identification of credible estimates. Comparisons of countries, and even federal states within a country, are critical and common trend assumptions in country-

\footnotetext{
${ }^{8}$ According to Saez (2001), the optimal-tax literature mostly interests theorists and does not make an impact on applications. This disconnect between the theoretic optimal-tax literature and the applied-empirical literature may be among the reasons why actual tax policies are rarely evaluated in the light of optimal-tax laws. Sørensen (2007) discusses the political relevance of the theory of optimal taxation.

${ }^{9}$ For example, it has been shown that corporate tax policies affect location decisions (e.g., Devereux and Griffith 1998), investment behavior (e.g., Feld and Heckemeyer 2011), financing decisions (e.g., Graham 2003) or choice of organizational form (e.g., de Mooij and Nicodeme 2008). Devereux et al. (2014) present a more detailed overview of this literature.
} 
level analyses over time are often hard to establish. We aim to overcome these shortcomings by relying on the case of German local business and property taxes in both an event-study and DiD research design with many independent tax-setting municipalities which operate in a homogeneous economic environment.

There are a few papers that identify the effect of business/corporate taxes on tax revenues or tax bases. Devereux et al. (2014) examine the elasticity of corporate taxable income in the UK. Using kinks in the corporate tax schedule, the paper finds moderate elasticities that differ depending on which kink is examined. Dwenger and Steiner (2012) study a reform of the federal German corporate tax to estimate an elasticity that is slightly larger than the ones in Devereux et al. (2014). In contrast to these papers, our estimations are not based on a short time period or a single tax reform but exploit various tax rate changes in a panel over many years. ${ }^{10}$

A few papers study the sensitivity of the business-tax base in the same institutional setting that we use. Buettner (2003) finds a very large effect on the tax base, suggesting that the municipalities are on the downward-sloping part of the business-tax Laffer curve. Baskaran $(2015)^{11}$ does not find any significant effects of the business tax on tax revenues; this is in line with our findings. These studies of Buettner (2003) and Baskaran (2015) are based on data from only one (out of 16) federal states while we use country-wide data. Fossen and Steiner (2014) use firm-level data to study how firms respond to changes in municipality-level tax rates. Their findings suggest that firms reduce their taxable income by about $0.5 \%$ in response to a $1 \%$ increase in the tax rate, suggesting that municipalities can raise extra tax revenues through higher tax rates despite a significant tax-base response. In contrast to the long panel we are able to rely on, Fossen and Steiner (2014) only use data from two years which complicates standard common trend assumptions. In general, our analysis intends to complement the few empirical papers, and adds to the important understanding of behavioral responses of firms to profit taxation.

Third, our work adds to a very small literature on the sensitivity of property to taxes. One recent study is Baskaran (2015), which uses the same institutional set-up as we do, though only for one federal state, and finds that the tax-revenue elasticity of property taxes is close to unity. Stine (1988) uses local-level panel data from

\footnotetext{
${ }^{10}$ Additional papers on the effect of corporate taxation on the tax base and revenues in nonGerman countries include Gruber and Rauh (2007) who use accounting data that are subject to the usual concerns with these type of data. Clausing (2007), Devereux (2007), and Brill and Hassett (2007) employ country-level regressions but do not include country fixed effects, which makes the results questionable. Mintz and Smart (2004) and Dahlby and Ferede (2012) use within-country variation in Canada. Kawano and Slemrod (2015) study corporate-tax-base responses in a panel of OECD countries.

${ }^{11}$ This paper focuses solely on the revenue elasticities of the local taxes, while we focus on the implications of our revenue-elasticity estimates for the inverse-elasticity rule.
} 
New York State and finds that the property tax base does not respond strongly to tax-rate changes. The findings in both these studies are consistent with our findings.

The paper proceeds as follows. Section 2 illustrates the institutional background. Section 3 describes the data sources and provides summary statistics. Section 4 lays out our empirical approach and identification strategies and Section 5 presents the results. We discuss our findings and provide evidence on potential mechanisms in Section 6. Section 7 concludes the paper.

\section{Institutional background}

While most taxes are set at the federal level in Germany, German municipalities are granted the right to set a business tax (Gewerbesteuer, short: BT) and a property tax (Grundsteuer, short: PT) autonomously. This implies that the business and property tax are set locally by each of more than 11,000 municipalities (Gemeinden) that are spread around the entire country. Business and property tax revenue are two of the most relevant sources of income of German municipalities. ${ }^{12}$ The business tax is the most abundant tax on profits in Germany. Total (gross) business tax revenue amounted to 43 billion EUR in 2013, this corresponds to about $7 \%$ of total national tax revenues. Property tax income summed up to 12.4 billion EUR in 2013.

\subsection{Business taxation}

The business tax is levied on operating profits and applies to both corporate and non-corporate firms. ${ }^{13}$ The tax base for the local business tax is legally defined by the federal government and cannot be affected by the municipalities. The federal government also sets a basic federal tax rate (Steuermesszahl, $\tau_{\text {fed }}^{B T}$ ), but the local municipalities choose the multiplier (Hebesatz, $m_{i}^{B T}$ ). The actual business tax rate is derived by multiplying the local tax multiplier with the basic federal tax rate. ${ }^{14}$ The local tax rate $\tau_{i}^{B T}$ on business profits in a municipality $i$ equals: $\tau_{i}^{B T}=\tau_{\text {fed }}^{B T} \times m_{i}^{B T}$. The basic federal tax rate, $\tau_{\text {fed }}^{B T}$, was set at 5\% until 2007 and was decreased to

\footnotetext{
${ }^{12}$ Other major municipal income sources are the municipal shares of the VAT and the federal income tax, duties and charges as well as municipal fiscal equalization transfers.

${ }^{13}$ In addition to the local business tax, corporate firms and non-corporate firms are also subject to federal corporate and income taxes, respectively. Subject to certain restrictions, non-corporate firms may deduct the local business tax from the federal income tax. Most companies in the agricultural and public sector as well as self-employed and freelancers are exempted from the local business tax.

${ }^{14}$ Strategic profit shifting of corporations with multiple establishments to exploit differences in local business tax multipliers is illegal and very difficult given formula apportionment rules in Germany.
} 
$3.5 \%$ since 2008. That is, a multiplier $m_{i}^{B T}$ of $300 \%$ implied a local business-tax rate of $15 \%$ before 2008 and $10.5 \%$ since 2008. ${ }^{15}$ There are no kinks in the tax schedule and the tax rate is not graduated so that marginal tax rates equal average tax rates. With regard to the period of interest, two relevant reforms took place in Germany on the federal level: First, the tax on business capital was abolished in 1998, reducing the tax base of the business tax. Second, since 2008 the business tax is no longer deductible as a business expense widening the tax base. These two reforms affected all municipalities and firms in the country equally, and therefore should not confound our results. Business tax multipliers varied between 30 and 600 during the time period 1995 to 2010 and averaged about 325 .

Figure 3 in Section 6 provides an overview of the development of average multipliers for both business and property tax rates over time. More summary statistics can be found in Section 3.2.

\subsection{Property taxation}

The property tax works much in the same way as the business tax; the tax base and the basic federal rate are defined at the federal level, and the municipalities only decide upon the property-tax multiplier. The German property tax system distinguishes two categories of property: property used for agricultural and forestry (property tax A) and constructible property or property with buildings (property $\operatorname{tax} B$ ). In this paper, we focus on the latter, i.e. the property tax on buildings and constructible property, because the tax on agricultural and forestry property is of minor importance for a municipality's tax revenue. The tax base is a standardized value (Einheitswert) of the property (and not the market value). ${ }^{16}$ As with the business tax, the property tax in a municipality $i$ depends on the federal rate and the multiplier, i.e., $\tau_{i}^{P T}=\tau_{\text {fed }}^{P T} \times m_{i}^{P T}$. The basic federal tax rate depends on the type of building and also varies between West and East Germany. Depending on the type of property, the rates vary between 0.26 and $0.35 \%$ in West Germany and between 0.5 and $1 \%$ in East Germany. The differences between East and West Germany account for the different definitions of the standardized value (which is the tax base) in the two parts of the country and are intended to make the multiplier rates comparable

\footnotetext{
${ }^{15} \mathrm{~A}$ minimum multiplier (floor) of $200 \%$ was implemented in 2004 to avoid detrimental tax competition. However, only 18 out of more than 11,000 municipalities had set a multiplier below $200 \%$ before this reform.

${ }^{16}$ The standardized values do not fairly reflect today's real property value (although they are supposed to according to the legal basis). This is only one of the reasons why the reform of the property tax is subject to frequent debate.
} 
between East and West Germany. ${ }^{17}$ Property tax multipliers varied between 50 and 810 during the time period 1995 to 2010 and averaged about 313.

\subsection{Comparability of business and property tax rates}

In evaluating whether German municipalities apply the inverse-elasticity-rule when setting the multiplier tax rates for the property and business tax, we imply that the multipliers are comparable between these two types of taxes. At first glance, this seems to be a strong assumption because the tax bases appear to be very different: operating profits of firms are the tax base in case of the business tax, and standardized property values are the base for the property tax. However, we do not compare the effective tax rates but rather use the multiplier rates for comparison.

These multiplier rates are not directly applied to the respective tax bases (profits or property). Instead, the base is multiplied with the federal tax rate ("Steuermesszahl") and then the multipliers are applied (recall: $\tau_{i}=\tau_{f e d} \times m_{i}$ ). We argue that the substantially different levels of the federal tax rate (recall: between 3.5 and $5 \%$ for the business tax and between 0.26 and $1 \%$ for the property tax) account for the different nature of the tax bases, and make the multiplier rates comparable between the two types of taxes. This is supported by the levels of multipliers that we observe. Although the tax bases are so different in nature, the multipliers for both taxes range between very similar levels. During the time period that we examine, average multipliers ranged between 312 and 338 for the business tax and 292 and 329 for the property tax. Hence, the multipliers appear to be on similar and comparable levels. ${ }^{18}$

An additional indication for our argument of comparable multipliers is that fiscal equalization within Germany is based on multipliers. Note that fiscal equalization payments are an important source of revenue of German municipalities. In fact, state-specific reference multipliers - and not actual local multipliers - are applied to calculate the fiscal capacity of a municipality, where this fiscal capacity determines equalization payments (Arnold et al. 2015). State governments apply standardized tax rates (Baskaran 2014), which are either set via reforms or as a weighted average of all municipalities in that state in preceding years, for the definition of rule-based grants to the municipal-level in order to alleviate tax rate competition. However,

\footnotetext{
${ }^{17}$ Since our data is on the municipality level, we do not have information on the distribution of property types, hence do not know the respective federal tax rates. This is one reason why we use the multipliers rather than the effective tax rates in our empirical analyses.

${ }^{18}$ The view that the federal rates are adjusted to make the tax multipliers comparable is supported by the fact that the federal rates for the property tax are different for East and West Germany due to different definitions of the standardized property values.
} 
state reference rates are very similar or often the same for local business tax and property tax rates (Landkreistag 2017). Therefore, state-wide standardization of tax policy likely leads to a harmonization of tax rates within state and substantially contributes to the comparability of the local business and property tax.

A further approach to compare the tax rates of the two tax instruments is to account for the different types of tax bases and estimate the tax rate on 'profits' that are implied (see section 6 for a detailed explanation).

\section{Data}

This section provides an overview of our data, summary statistics and outlines the identifying variation in both types of tax rates that we use in our empirical analysis.

\subsection{Data sources}

We construct a unique data set on German municipalities using and combining different sources of administrative data. Our municipality-level data on tax rates, tax revenues and population come from the statistical offices of the federal states. ${ }^{19}$ Municipality-level employment statistics are provided by the Federal Employment Agency (Bundesagentur für Arbeit). We further add variables on the county-level (GDP, level of debt, disposable income of private households) for the years 19952010, which come from a different data source at the statistical offices of the federal states. Note that each of about 400 counties either comprises several municipalities or constitutes a single municipality.

Due to data restrictions, we gather our sample from the years 1995-2010 as most federal states do not provide data earlier than the 1990s. In addition, the county-level variables are as well only available since 1995. This is the reason why we base our baseline estimations on the period 1995-2010. We also run sensitivity checks with a longer time-series but fewer federal-states (not reported). To obtain comparable elasticity measures, we restrict our empirical analysis to those municipalities for which we have complete information on the business-tax and propertytax rates and revenues. We further exclude municipalities with negative business or property tax revenue in a certain year from our empirical analysis since actual

\footnotetext{
${ }^{19}$ The most recent data, since 2009, are available online at the so-called Regional Database Germany (Regionaldatenbank). Data for the years between 2001 and 2008 are made available on DVDs (called Statistik Lokal) that can be purchased directly from the federal statistical office. Earlier data before 2001 are retrieved on request directly from the respective statistical offices of the federal states. This is the reason why the time dimension of our data set varies by state. For example, while our oldest data on the PT and BT go back to the 1970s (Bavaria), MecklenburgVorpommern could only provide data since 1998. Results are robust to longer panel data.
} 
revenues cannot be negative but are only reported to be negative due to accounting procedures. In total, the data in our baseline analysis contain about 170,000 municipality-level observations in the 16-year panel, 1995-2010 (see Table A.1 in the Appendix for more information). The next section provides summary statistics.

\subsection{Summary statistics and identifying variation}

Table 1 provides descriptive statistics for our baseline sample during the period 1995 to 2010. Average tax revenue from the business tax (BT) is much higher than from the property tax $(\mathrm{PT})$, suggesting that the business tax is more important for the municipalities. The table also shows that there is great heterogeneity across municipalities w.r.t. to population size (between 10 and 3.5 million inhabitants). The fact that the average BT multiplier is higher than the average PT multiplier is at the center of this paper, and will be discussed in more detail below.

Table 1: Summary statistics, 1995-2010

\begin{tabular}{lccccc}
\hline \hline \multicolumn{1}{c}{ Variable } & Mean & Std. Dev. & Min. & Max. & N \\
\hline Revenue BT (1,000 EUR) & 2651.616 & 28204.096 & 0.005 & 2078955 & 174670 \\
Revenue BT (log 1,000 EUR) & 4.91 & 2.501 & -5.276 & 14.547 & 174670 \\
Multiplier BT (\%) & 324.885 & 37.755 & 30 & 600 & 174670 \\
Multiplier BT (log \%) & 5.776 & 0.121 & 3.401 & 6.397 & 174670 \\
Revenue PT (1,000 EUR) & 808.975 & 8033.088 & 0.511 & 747238 & 174670 \\
Revenue PT (log 1,000 EUR) & 4.799 & 1.694 & -0.671 & 13.524 & 174670 \\
Multiplier PT (\%) & 313.119 & 45.87 & 50 & 810 & 174670 \\
Multiplier PT(log \%) & 5.736 & 0.146 & 3.912 & 6.697 & 174670 \\
GDP (1,000 EUR) & 3773758.17 & 3354230.616 & 671848 & 98751797 & 158540 \\
Population (1,000) & 7.183 & 46.607 & 0.01 & 3471.418 & 174418 \\
Population (sq 1,000) & 2223.819 & 117169.293 & 0 & 12050743 & 174418 \\
Debt (1,000 EUR) & 157390.836 & 119370.435 & 0 & 3414334 & 162730 \\
Private income (1,000 EUR) & 2845050.66 & 1934041.044 & 488465 & 31811513 & 150270 \\
Employees & 2549.232 & 18909.947 & 0 & 1158925 & 158700 \\
\hline
\end{tabular}

Notes: Summary statistics. Municipal level variables: BT and PT revenue and multiplier, population and number of employees. County level variables: level of debt, income of private households and GDP. Administrative data on the universe of German municipalities collected from the statistical offices of the German federal states. Years 1995 to 2010. Restricted to observations for which information on BT and PT were available. Observations excluded if revenue is reported negative.

Our identification strategy rests on within-municipality variation in tax rates over time. Table 2 provides an overview of variation in the business-tax and propertytax multipliers. For each year of our baseline sample, it depicts the share of municipalities which change their $\mathrm{BT}$ and $\mathrm{PT}$ rates in year $t$ compared to year $t-1$. On average, $8 \%$ and $10 \%$ of the municipalities change their BT and PT multipliers per 
year, respectively. Thereby, the BT tends to be more stable than the PT and the share of municipalities that changed the PT is higher each year.

Table 2: Share of municipalities with changing BT and PT multipliers (in \%)

\begin{tabular}{lrr}
\hline \hline Year & Change BT & Change PT \\
\hline 1995 & 14.40 & 18.97 \\
1996 & 8.45 & 10.60 \\
1997 & 8.83 & 12.94 \\
1998 & 8.96 & 12.40 \\
1999 & 4.63 & 6.25 \\
2000 & 5.02 & 5.95 \\
2001 & 8.01 & 8.30 \\
2002 & 7.96 & 9.97 \\
2003 & 9.69 & 13.35 \\
2004 & 8.81 & 13.26 \\
2005 & 11.12 & 14.98 \\
2006 & 8.20 & 9.98 \\
2007 & 4.50 & 5.70 \\
2008 & 4.29 & 5.00 \\
2009 & 4.84 & 5.07 \\
2010 & 9.79 & 12.88 \\
Total & 7.82 & 10.14 \\
\hline \hline
\end{tabular}

Notes: Share of municipalities which change their business tax (BT) and property tax (PT) multipliers between years.

Figure 1 shows the size distribution of tax rate changes for the business and property tax, respectively. It becomes apparent that there are more tax rate increases than decreases for both tax types and only a small share of municipalities implement multiplier changes that exceed 50 percentage points. The mean change for business tax and property tax rates is about 1.28 and 2.33 percentage points, respectively. Altogether, we observe 26,393 tax reforms in our sample period for both the business tax and property tax. The business and property tax accounts for 11,496 and 14,897 changes, respectively.

Tables A.2 and A.3 in the Appendix provide further detailed information on the size and direction of the changes that we exploit for identifying variation. Most of the changes are in the range between 1 and 50 percentage points. ${ }^{20}$

\footnotetext{
${ }^{20}$ The spatial variation of tax rate choices over time is visualized in Appendix Figures A.1 and A.2. The figures depict maps of Germany showing the levels of business taxes and property taxes in 2001 and 2010, respectively.
} 


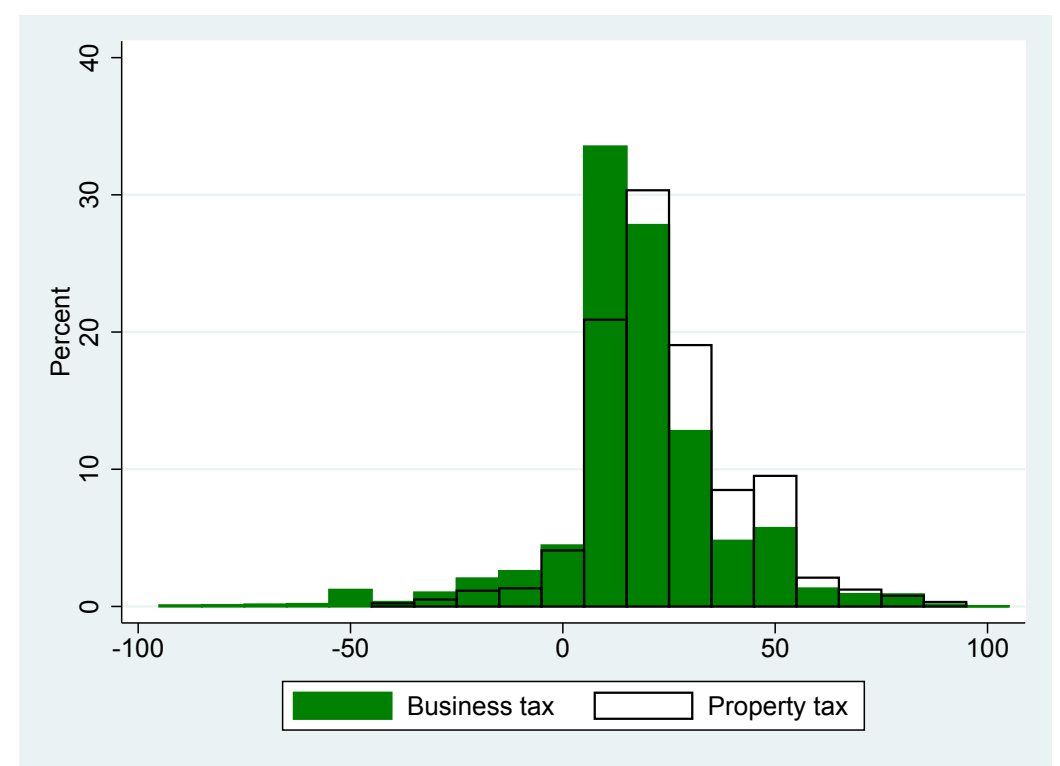

Figure 1: Size of tax rate changes of Business and Property tax

Notes: Frequency distribution of the size of yearly tax rate changes in 1995-2010 for business (green) and property (white) tax rates in percentage points, respectively. The plot only considers actual tax rate changes, i.e. the yearly difference is not equal to zero. Hence, the plot considers 11,496 business and 14,897 property tax reforms in the sample period. For illustrative purposes we omit the lowest and highest percentile of tax rate change sizes for the business and property tax, respectively.

\section{Empirical strategy and identification}

We use two different empirical strategies to estimate the effect of local business and property tax rates on their respective tax revenues. First, we use an eventstudy design which allows us to show the dynamics of local tax reforms on the respective revenues and to provide an illustration of common pre-trends in revenue outcomes before tax reforms; i.e. studying if there are no significant revenue effects preceding a tax rate reform. Second, we estimate the average treatment effects of tax rate changes for both types of taxation in a generalized DiD model. While the DiD specifications give us the magnitude of revenue changes triggered by local tax reforms, we can establish the absence of diverging pre-trends using event-studytype estimations. In general, our empirical design is very similar to the empirical set up in Fuest et al. (2017). They also use local taxation in German municipalities for identifying variation and employ both event studies and DiD. However, they focus on the tax effects on wages - while we look at revenues - and focus solely on business-tax rates - while we study variation in both business and property taxes. ${ }^{21}$

Our outcome variables throughout are tax revenues from either the business

\footnotetext{
${ }^{21}$ Fuest et al. (2017) provide extensive checks to validate the identifying assumptions behind the empirical approach.
} 
or property tax rate in a given municipality and year. We denote these outcomes as $Y_{i, t}^{j}$, where $i$ and $t$ indicate the municipality and year, and $j$ indicates the respective tax type: either business tax (BT) or property tax (PT).

Event-study. We start out by estimating the following event-study regression:

$$
\log Y_{i, t}^{j}=\sum_{w=-4}^{4} \gamma_{w}^{j} D_{i, t}^{j, w}+\beta_{1}^{j} \mathbf{X}_{i, t-1}+\beta_{2}^{j} \mathbf{Z}_{c, t-1}+\lambda_{i}+\phi_{t}+\phi_{t} \times \eta_{s}+\mu_{i, t}^{j} .
$$

Dummy variables $D^{j, w}$ indicate an event for tax type $j$ that happens $w$ periods away from $t$. Our effects of interest are the coefficients $\gamma_{w}^{j}$ for each of these dummy variables. Following Fuest et al. (2017), we study three types of 'events' for identifying variation: (i) large tax hikes, (ii) all tax hikes and (iii) all tax rate reductions. In regressions with business-tax revenues as outcome variable, the respective events are defined based on reforms of the business-tax rate. Accordingly, events are based on property-tax reforms when property-tax revenues constitute the outcome variable. We define large hikes as any yearly tax-rate increases which exceed the 75th percentile of all tax increases of tax $j$ in year $t$. Figure A.3 of the Appendix gives the number of reform events by type for the business tax and property tax, respectively. We observe a fairly large number of about 2800 'large' increases for business taxes and about 4400 'large' increases for property tax rates. ${ }^{22}$ The number of tax decreases is relatively small with 1219 and 812 related tax rate changes, respectively. Distinguishing these events allows us to estimate the respective revenue effect of different types of events; this is advantageous because large reforms might have different effects than small reforms (e.g., due to adjustment costs).

We estimate the event-study with an event window running from 4 years prior to a reform up to 4 years after the reform. The event-type model allows thus to check for potentially diverging pre-trends in the 4 years prior to the tax reform and to estimate lagged revenue effects in the 4 years after the event. These dynamics are important: the pre-trends lend credibility to our identification and the dynamics post reform shed light on lagged effects of tax reforms. Note that our results are robust to using longer or shorter event windows. ${ }^{23}$ In line with the literature, we bin up event dummies at the end points of the event window. So the dummies $D_{i, t}^{j, 4}$ and $D_{i, t}^{j,-4}$ account for all events four or more years away from the event. This is necessary because reform years differ across municipalities. Because of this procedure, we do

\footnotetext{
${ }^{22}$ Large hikes for business (property) tax amount to 28.57 (32.67) percentage points on average.

${ }^{23}$ See Appendix C for graphical illustrations of the 5-5 and 3-3 year event window specifications.
} 
not plot the endpoint estimates in our event-study graphs.

Following examples in the literature (Fuest et al. 2017; Simon 2016), we impose the following sample restrictions to implement the event studies. First, we exclude municipalities that implemented another type of event during the sample period. More specifically, when considering tax hikes (either large or all tax hikes) we exclude municipalities that implemented decreases during the sample period. Accordingly, we exclude municipalities with increases when considering tax reductions (and vice versa). This eliminates the risk that other types of reforms confound our effects of interest. Second, we balance the sample by dropping observations for which we do not observe the entire event window around a given tax reform. That is, for example, a 1997 reform is not considered because 1993 (i.e., four years before the reform) is not in our sample. Third, we use a balanced sample where we only include municipalities that are included in each year of the sample period. Some East German municipalities were merged during the sample period, making the raw panel unbalanced. However, our event-study set up requires balanced data.

We add municipality fixed effects $\left(\lambda_{i}\right)$, year fixed effects $\left(\phi_{t}\right)$ as well as federalstate specific year effects $\left(\phi_{t} \times \eta_{s}\right)$ to the regressions - the latter set of fixed effects particularly accounts for regional shocks. We also include several (lagged) control variables to account for time-varying and pre-determined local shocks to municipal budgets. First, we control for time-varying factors $\mathbf{X}_{i, t}$ on the level of municipality $i$ which include population (in levels and squares) and the total number of employees. Second, we further account for potential confounders $\mathbf{Z}_{c, t}$ on the county-level $c$ such as GDP, level of debt as well as disposable income of private households. $\mu_{i, t}$ is our error term. ${ }^{24}$ Standard errors are clustered on the municipality level which is the aggregation level of the identifying variation.

Differences-in-differences. While our event-study design mainly serves the purpose of establishing flat pre-trends (see Section 5 below) and checking the dynamics of the effects, we use a generalized DiD model to estimate the average treatment effects of tax rate changes on tax revenues. This model formally reads:

$$
\log Y_{i, t}^{j}=\epsilon^{j} \log m_{i, t-1}^{j}+\beta_{1}^{j} \mathbf{X}_{i, t-1}+\beta_{2}^{j} \mathbf{Z}_{c, t-1}+\lambda_{i}+\phi_{t}+\phi_{t} \times \eta_{s}+\mu_{i, t}^{j} .
$$

Again, the dependent variable, $Y_{i, t}^{j}$, is tax revenue (in EUR) generated from

\footnotetext{
${ }^{24} \mathrm{We}$ also control for a full set of event dummys indicating tax hikes and reductions in the event window for the property tax (business tax) when analyzing the effects of the business tax (property tax). This is to avoid that our business tax (property tax) estimates are driven by simultaneous changes in property taxes (business taxes).
} 
the tax of type $j$ (either business or property) in municipality $i$. The explanatory variable of interest is the lagged (business or property) tax multiplier $m_{i, t-1}^{j}$. Note that the generalized DiD model includes a full set of lagged control variables on the municipal $\left(\mathbf{X}_{i, t-1}\right.$ : population in levels and squares and the total number of employees) and county level ( $\mathbf{Z}_{c, t-1}$ : GDP, level of debt as well as disposable income of private households); these are the same control variables that are included in the event studies above. We also add municipality $\left(\lambda_{i}\right)$, year $\left(\phi_{t}\right)$ and state-year $\left(\phi_{t} \times \eta_{s}\right)$ fixed effects. Tax revenues and tax rates enter the regression in logs to derive an elasticity interpretation of the effect of tax rates on revenues. The elasticity of interest for tax of type $j$ is denoted $\epsilon^{j}$.

Identification. Each of the about 11,000 municipalities annually sets the tax rate multiplier for year $t$ in the last months of year $t-1$, and our data cover the universe of all municipalities and span a long time period (see Section 3.2 for details on the variation in tax rates). This institutional set up generates many differential tax rate changes, motivating the use of event-studies and generalized DiD.

The identifying assumption is that municipalities with tax rate changes would have had the same development of tax revenues as municipalities without tax rate changes, had they not implemented a tax rate change.

This assumption is violated if, for example, local economic conditions force certain municipalities to change rates, whereas other municipalities face other, less pressing local economic conditions. We take two steps to alleviate this possible threat to identification (as in Fuest et al. 2017): First, we include federal-state (Laender) specific year effects that control for any economic shocks on the federalstate level. Since federal states constitute homogeneous economic environments, it is unlikely that a certain economic shock hits municipalities within a federal state differently. Second, in addition to wiping out time-invariant municipality effects, we control for time-varying municipality characteristics such as size as well as economic conditions such as GDP, level of debt or number of employees. This implies that we only compare municipalities with similar characteristics and economic conditions. In addition, previous evidence shows that tax changes are usually implemented for political, rather than economic, reasons (such as upcoming elections), suggesting that local economic conditions play a minor role in explaining tax changes (see e.g., Castanheira et al. 2012; Foremny and Riedel 2014; Fuest et al. 2017). ${ }^{25}$

\footnotetext{
${ }^{25}$ Some of the covariates that we include to control for economic conditions might be endogenous to tax-rate changes. To account for this, we throughout present regression specifications without covariates. There might be additional factors which are omitted from the regression due to data restrictions, for example environmental regulation. However, the resulting bias is arguably small, if at all existing, because most environmental regulations are set on the federal or state level and
} 
Our event-studies serve the prime purpose of testing if municipalities implementing a reform have different developments of tax-revenue prior to the reform. Since tax revenues are a good indicator of local economic conditions, the flat pretrends that we establish below alleviate identification concerns. Furthermore, Fuest et al. (2017), who use the same variation in business taxes that we use, provide careful tests showing that local economic conditions such as GDP and unemployment do not drive tax changes.

One other concern with many empirical tax studies is that tax reforms often come with changes in tax rates and tax base definitions (e.g., tax-rate-cut-cum-basebroadening type reforms). Kawano and Slemrod (2015) provide empirical evidence that tax changes are usually accompanied by tax-base changes. This is not a concern in our set-up: any changes in tax base definitions are legislated on the federal level and are accounted for by the year fixed effects. Reverse causality is not likely to bias our results either. The timing of events is such that municipalities usually set the multiplier in the last months of year $t-1$; that is, before they are aware of tax revenues in year $t$. Reverse causality, however, remains a potential problem if municipalities have precise expectations in $t-1$ regarding tax revenue in year $t$. We apply two procedures in order to deal with this claim. First, our event-study design allows us to establish flat pre-trends which indicate that tax reforms are not driven by tax-revenue considerations. Second, we use lagged tax rate multipliers in the DiD setting to alleviate concerns of reverse causality. We also introduce several time-varying control variables which are lagged by one year to address this issue.

A further identification concern relates to tax competition effects and the potential dependency of tax policies across neighboring municipalities. ${ }^{26}$ Recent empirical evidence using the same institutional set-up as ours by Baskaran (2014), however, does not find any sort of tax mimicking and therefore neglects this possible source of bias. His paper shows that following an exogenous tax reform that provided municipalities in one federal state with an incentive to change rates, neighboring municipalities in other federal states did not adjust their rates in response. ${ }^{27}$

In general, the empirical set-up is advantageous in light of the purpose of this paper: we aim to compare tax responses of two different taxable goods. We do this looking at the same municipalities over the same time period using the exact

therefore accounted for in the time and regional-specific time fixed effects.

${ }^{26}$ We abstain from including neighborhood measures of local tax rates such as spatial lags in our baseline as they might be endogenous to the tax rate of the municipality under consideration, representing a bad control in the spirit of Angrist and Pischke (2009). Controlling for county averages of local tax rates (except the respective tax rate of town $i$ ) does, however, not change our results, respectively.

${ }^{27}$ Lyytikäinen (2012) finds similar results for property taxes in Finland. Moreover, Isen (2014) shows that there are no local spillovers of sales, bond, property or income taxes in the US. 
same identification strategies and data. If any sources of endogeneity remain despite our research design, the resulting bias will be similar for the property and business tax elasticities, hence ensuring that the relative magnitudes of the estimates are comparable.

Tax-base vs tax-revenue elasticities. The inverse-elasticity rule is regarding the responsiveness of tax bases, rather than the responsiveness of tax revenues. However, data restrictions do not allow us to study the effect of taxes on tax bases and we instead estimate the effect on tax revenues (see footnote 2 and Section 2.2). To see the relationship between the tax-base elasticity and the tax-revenue elasticity, consider the simple inverse-elasticity rule:

$$
\tau_{1} \eta_{1}=\tau_{2} \eta_{2}
$$

where $\tau_{j}$ and $\eta_{j}$ (with $j \in 1,2$ ) are the tax rate and the tax-base elasticity of goods 1 and 2 (i.e., property and business profits), respectively. The tax base is denoted $B_{j}$ and the term for the tax-base elasticity is: $\eta_{j}=\frac{\Delta B_{j}}{\Delta \tau_{j}} \frac{\tau_{j}}{B_{j}}$. Tax revenue $T R_{j}$ is given by $T R_{j}=\tau_{j} B_{j}$, and changes in tax revenue are then:

$$
\Delta T R_{j}=\Delta \tau_{j} B_{j}+\tau_{j} \Delta B_{j}=\Delta \tau_{j} B_{j}+\eta_{j} B_{j} \Delta \tau_{j}=B_{j}\left(1+\eta_{j}\right) \Delta \tau_{j}
$$

To derive the elasticity of tax revenue, we divide the above equation by $T R_{j}=\tau_{j} B_{j}$ and rearrange the equation:

$$
\frac{\Delta T R_{j}}{\Delta \tau_{j}} \frac{\tau_{j}}{T R_{j}}=\left(1+\eta_{j}\right)
$$

The left-hand-side in this equation is the elasticity of tax revenue with respect to the tax rate, which is the parameter that we identify from our empirical estimates (denoted $\epsilon^{j}$ in the regression equation above). The equation shows that our empirical estimate equals $\left(1+\eta_{j}\right)$, and hence has a direct relationship with the elasticity of the tax base. In particular, a high elasticity of tax revenues is associated with a low (in absolute terms) elasticity of the tax base, and vice versa. In the extreme case where our revenue elasticity would be estimated to be $1(0)$, the associated tax-base elasticity is $0(-1)$. Note that we expect the tax-revenue elasticity to be positive and the tax-base elasticity to be negative. This exercise of course neglects the role of deductions and credits, but shows the general relation between the elasticities of the tax base and tax revenue. 


\section{Results}

\subsection{Event-study design}

We first present our results on tax revenue effects of local tax reforms using our event-study design from equation (1) for property and business tax rate changes in Panel (a) and (b) of Figure 2, respectively. As usual with event studies, we present the results in event-study graphs that plot the coefficients. The dummies indicating the year before the reform are always omitted so that all effects are relative to the year before an event. The full regression results of the baseline scenario with an event window of 4 years prior to and after individual tax reform events are also shown in Table C.1 in the Appendix. As described before, we show the revenue effects for three types of tax reforms, each for both types of taxes: large tax hikes only, any tax rate increases and any decreases.

Panel (a) in Figure 2 shows the significant and substantial revenue effects from changes in property tax rates. We find positive and highly significant revenue effects from property tax increases which materialize immediately and remain substantial over time. Corresponding with intuition, larger tax rate increases yield somewhat higher tax revenues than all increases on average. We further observe that tax decreases result in immediate negative and significant drops in tax revenues.

Most importantly, the graphs show very flat revenue trends preceding the reforms; neither type of property-tax reform is determined by significant tax revenue trends before the reform events. ${ }^{28}$

Panel (b) of Figure 2 shows the equivalent event-study graphs for the effect of business-tax rates on business-tax revenues. We again observe flat pre-event trends, meaning that there are no significant revenue effects for the years before the reform. ${ }^{29}$ Considering the effects of 'Large hikes', we mostly do not see any significant postevent effects. We observe slightly significant post-event effects when we consider tax hikes of all sizes. However, the point-estimates are not very large. Note that for both taxes, decreases in tax rates are relatively rare and accordingly, estimates are relatively noisy. Overall, the event-study results show larger and more precise revenue effects of property-tax reforms relative to the revenue effects of business-tax reforms; compare Panels (a) and (b) in Figure 2.

\footnotetext{
${ }^{28}$ This is true although Table C.1 of the Appendix indicates that property tax increases in the specification 'Hike' show some significance for the tax hike coefficients 3 years before the reform. However, the point estimate is very small and the significance vanishes two years prior to the reform.

${ }^{29}$ The only pre-event significance that we see is for the F3 coefficient in the 'Hike' specification. However, this significance is only on the $10 \%$ level and the point estimate is comparable to the non-significant point estimate in the 'Large Hike' specification.
} 


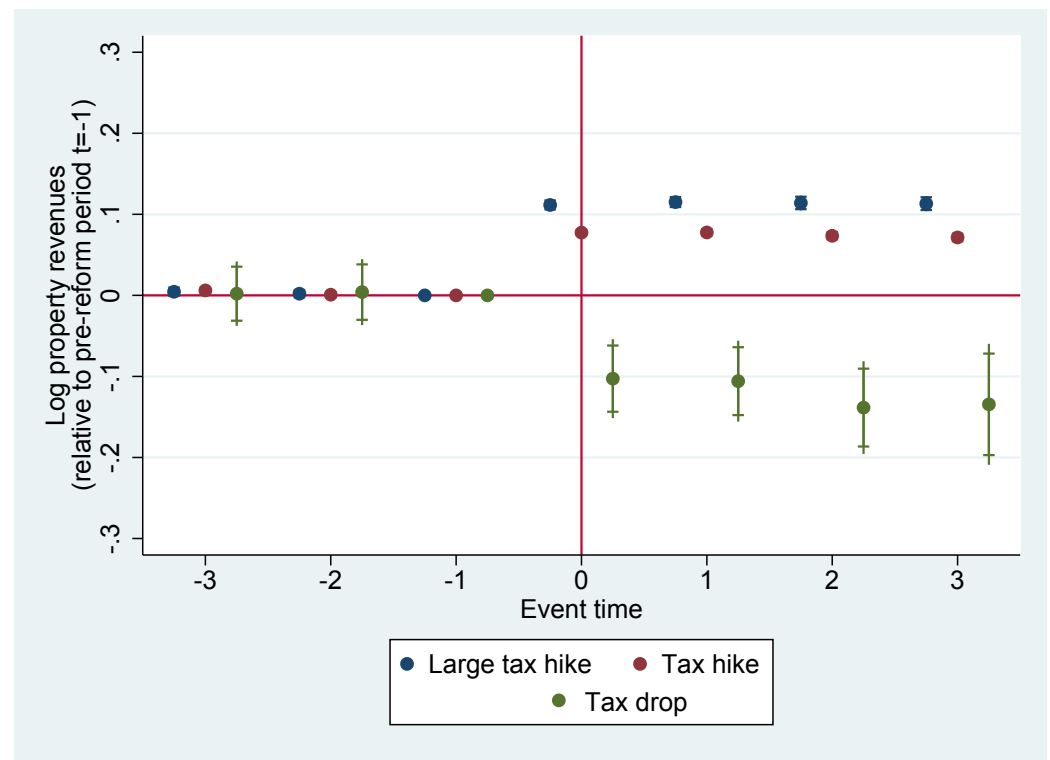

(a) Property tax

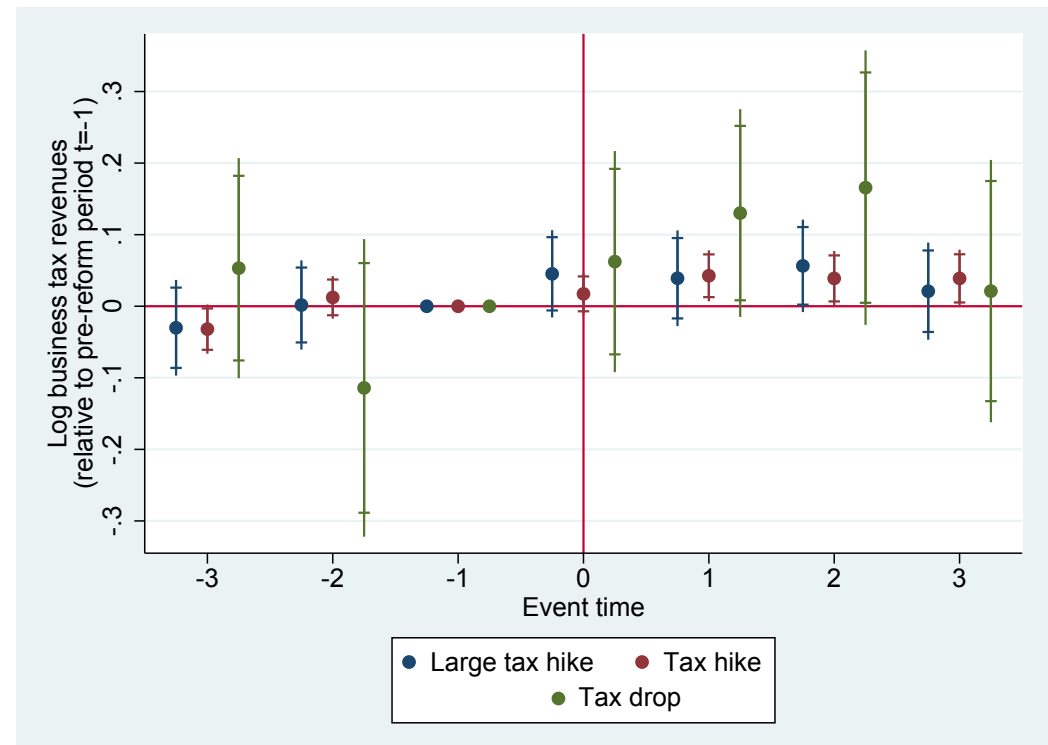

(b) Business tax

Figure 2: Event-study graphs: Baseline estimates

Notes: Panel (a) plots event study estimates for property tax rate reforms on the log property tax revenues. Panel (b) illustrates the related findings for the business tax. Both panels show eventstudy estimates $\left(\gamma^{j} ; j \epsilon[-3 ;+3]\right)$, i.e. without window ends, for the baseline scenario of a 4 to 4 year event window and the corresponding 90\% (vertical line) and $95 \%$ confidence bands (horizontal line) for different reform types of equation 1 . Event variables are dummies equal to one for a tax increase, a large tax increase (greater than or equal to the 75th percentile of the tax increase distribution), or a tax decrease (see legend). In specifications with tax increase (decrease) dummies, we exclude all municipalities that experienced a tax decrease (increase) during the observation period. We also balance our event-study such that only tax reforms are included that are observed throughout the whole event window, here 4 years before and after the reform. 
Figure C.1 and C.2 in the Appendix shows that our results are robust to longer or shorter event windows, i.e. including lead and lag dummies for both either 5 or 3 years before and after reform events. Changes in both the property and the business tax rates yield strikingly similar results to the findings in our baseline scenario: Property tax increases lead to significant increases from property tax revenues while business tax rate changes mostly do not yield significant revenue changes. Importantly, we also do not find significantly diverging pre-trends of tax revenue outcomes in the years preceding reform events for the business and property tax, respectively.

\subsection{Differences-in-Differences}

Main results. While our event-study design establishes flat pre-trends, we estimate the magnitude of the average treatment effects of tax rate changes on tax revenues in a generalized DiD setting.

Table 3 depicts our main regression results, estimated using equation (2). Columns (I) and (II) show that business-tax rate changes do not significantly affect business-tax revenues. This indicates that business profits respond very elastic to tax-rate changes. The elasticity of tax revenues with respect to a (lagged) change in the tax multiplier is about 0.12 and not statistically different from zero. That is, municipalities are not able to raise significant amounts of extra tax revenue by increasing business tax rates. The results are robust to the control variables included (columns (I) vs. (II)). Our elasticity estimates suggest that, because firms are tax responsive, tax rates in German municipalities are placed close to the peak of the Laffer curve. While these elasticities appear to be very low, they are still higher than the results in Buettner (2003) who finds that municipalities in the federal state of Baden-Wuerttemberg even loose tax revenue in response to tax-rate hikes.

Columns (III) and (IV) of Table 3 present the results for the property-tax elasticities. We find that, in contrast to business income, property is substantially less responsive to tax-rate changes. This confirms the findings from our event-study procedure in the previous section. A $1 \%$ increase in the (lagged) property-tax multiplier leads to a tax-revenue increase of about $0.67 \%$. The results are practically independent of the control variables we include (columns (III) vs. (IV)). The property tax elasticities are in line with intuition: physical property cannot be as mobile as business income and only responds slightly through, for example, long-term responses or avoidance/evasion channels. It may also be that building activities in non-affected municipalities grow quicker relative to those with property-tax changes. Recall that the event-study estimates in the previous section illustrated that the additional 
(foregone) property tax revenues from tax decrease (increase) slightly over time (see Table C.1 in the Appendix). The result that property becomes more mobile in the long-run is in line with the findings of Stine (1988). In light of the fact that we estimate property-tax and business-tax elasticities in the exact same institutional set-up using an identical research design, the plausibility of the property-tax estimates also lends credibility to our estimates for the business-tax elasticities.

Table 3: Effects of business and property taxes on tax revenues

\begin{tabular}{lcccc}
\hline & $(\mathrm{I})$ & $(\mathrm{II})$ & $(\mathrm{III})$ & $(\mathrm{IV})$ \\
& \multicolumn{1}{c}{ Revenue business tax } & Revenue property tax \\
\hline$m_{t-1}^{B T}$ & 0.081 & 0.117 & & \\
& $(0.096)$ & $(0.090)$ & & \\
$m_{t-1}^{P T}$ & & & $0.653^{* * *}$ & $0.668^{* * *}$ \\
& & & $(0.012)$ & $(0.011)$ \\
\hline Year FE & yes & yes & yes & yes \\
Municip. FE & yes & yes & yes & yes \\
State $\times$ Year FE & yes & yes & yes & yes \\
Controls & no & yes & no & yes \\
\hline $\mathrm{N}$ & 152,770 & 130,814 & 152,770 & 130,814 \\
$R^{2}$ & 0.150 & 0.153 & 0.588 & 0.668 \\
\hline \hline
\end{tabular}

Notes: Fixed-effects regressions based on equation $((2))$ with standard errors in parentheses. Standard errors clustered on the municipality level. Significance levels are ${ }^{*}<0.10,{ }^{* *}<0.05,{ }^{* * *}$ $<0.01$. Administrative data on the universe of German municipalities. Years 1995 to 2010. The unit of observation is a single municipality. Dependent variable in columns (I) and (II) is municipality-level tax revenue generated from the local business tax (BT), and municipality-level tax revenue from the local property tax (PT) in columns (III) and (IV). The independent variable of interest is the municipality-level tax multiplier $m$ in $t-1$ for the business or property tax. Reported coefficients can be interpreted as elasticities identified from tax reforms. All specifications include year fixed effects, municipality fixed effects, and federal-state specific year fixed effects. Columns (I) and (III) do not include controls. Columns (II) and (IV) add lagged controls for population, local GDP, level of debt, number of employees, and disposable income of private households.

Robustness checks. Our results are robust to a number of further sensitivity checks presented in Table B.1 in the Appendix. Panel A of the table depicts the results of regressions estimated on a balanced panel of municipalities. The results are almost unchanged. In Panel B, we present regressions which account for the fact that business and property tax rates are often jointly reformed and we drop all related observations to evaluate business and property tax reforms separately. The effects remain the same in magnitude and statistical significance.

Moreover, in Table B.2 in the Appendix we run additional sensitivity checks to examine whether our results are driven by modeling choice or the inclusion of 
further controls. All DiD baseline estimations include municipality, year as well as state-specific year fixed effects. Model (I) of Table B.2 includes district-specific time trends to aggregate for common economic shocks instead of state-specific year fixed effects but results do not change. Model (II) adds the state-specific year fixed effects and Model (III) includes socio-economic control variables on the town and county-level from our baseline. Again, for both taxes revenue elasticities remain unchanged. We also account for potential omitted variables by including different factors of relevance, i.e. spatial lags of tax rates (Model (IV)) or quadratic terms to account for non-linearities of tax rate effects on the respective tax revenues (Model $(\mathrm{V}))$.

Model (IV) includes spatial lags, i.e. that is the lagged average tax rate of all other municipalities in a given district (excluding the tax rate of municipality i), for the business tax or property tax rate in our baseline regression, respectively. Doing this, we want to account for potential spatial confounders in local tax policies which could affect the estimates of our tax revenue elasticities. Even though the coefficient of average tax rates in the county neighborhood appear to be partially significant (for the business tax, unreported), including spatial dependency does not invalidate our baseline findings and our results remain unchanged. Model (V), however, includes a quadratic term of the lagged log tax rate for the business tax or property tax rate, respectively. Non-linear effects of tax rates on related tax revenues might be plausible in a Laffer curve framework of U-shaped tax revenuetax rate relationship. The estimations for the business tax show both insignificant linear and non-linear terms of the tax rate coefficient which may be indicative that German municipalities are at the peak of the Laffer curve. The property tax rate, however, is likely to be at the upward-sloping path of the Laffer curve as higher tax rates yield significantly higher property tax revenues but at an decreasing rate. Hence, German municipalities could indeed increase their property tax rates in order to gain more revenues.

Table B.3 of the Appendix also investigates whether different clustering leads to changes in inference of our baseline estimates. In our baseline estimations we cluster at the municipal level to avoid bias from serial correlation. Table B.3 shows that standard errors hardly change when we conduct clustering of standard errors at higher levels of aggregation such as counties, states or year-specific interactions of these aggregations as suggested by Angrist and Pischke (2009).

Finally, we also examine if differences in elasticities are associated with different tax rates. Table 4 reports regression results separately for municipalities that have higher property-tax rates than business-tax rates (Panel A) and municipalities that impose a higher rate on business profits than on property (Panel B). Reassur- 
ingly, the coefficients in both panels reveal the same pattern as before for both types of municipalities, i.e. property-tax revenues are always far more responsive to tax rate changes than business-tax revenues - this holds even in those municipalities that impose higher taxes on business than on property.

Table 4: Tax-revenue elasticities. Heterogeneity w.r.t. tax-rate relation

\begin{tabular}{|c|c|c|c|c|}
\hline & (I) & (II) & (III) & $(\mathrm{IV})$ \\
\hline & \multicolumn{2}{|c|}{ Revenue business tax } & \multicolumn{2}{|c|}{ Revenue property tax } \\
\hline \multicolumn{5}{|c|}{ Panel A: Municipalities with $m^{B T}<=m^{P T}$} \\
\hline \multirow[t]{2}{*}{$m_{t-1}^{B T}$} & 0.079 & 0.117 & & \\
\hline & $(0.125)$ & $(0.123)$ & & \\
\hline \multirow[t]{2}{*}{$m_{t-1}^{P T}$} & & & $0.658^{* * *}$ & $0.671^{* * *}$ \\
\hline & & & $(0.026)$ & $(0.023)$ \\
\hline $\mathrm{N}$ & 67,697 & 51,940 & 67,697 & 51,940 \\
\hline$R^{2}$ & 0.166 & 0.167 & 0.441 & 0.478 \\
\hline \multicolumn{5}{|c|}{ Panel B: Municipalities with $m^{B T}>m^{P T}$} \\
\hline \multirow[t]{2}{*}{$m_{t-1}^{B T}$} & 0.158 & $0.280^{*}$ & & \\
\hline & $(0.154)$ & $(0.154)$ & & \\
\hline \multirow[t]{2}{*}{$m_{t-1}^{P T}$} & & & $0.661^{* * *}$ & $0.672^{* * *}$ \\
\hline & & & $(0.014)$ & $(0.014)$ \\
\hline $\mathrm{N}$ & 85,073 & 78,874 & 85,073 & 78,874 \\
\hline$R^{2}$ & 0.124 & 0.134 & 0.694 & 0.742 \\
\hline
\end{tabular}

Notes: Fixed-effects regressions based on equation $((2))$ with standard errors in parentheses. Standard errors clustered on the municipality level. Significance levels are ${ }^{*}<0.10,{ }^{* *}<0.05,{ }^{* * *}$ $<0.01$. Administrative data on the universe of German municipalities. Years 1995 to 2010. The unit of observation is a single municipality. Dependent variable in columns (I) and (II) is municipality-level tax revenue generated from the local business tax (BT), and municipality-level tax revenue from the local property tax (PT) in columns (III) and (IV). The independent variable of interest is the municipality-level tax multiplier $m$ in $t-1$ for the business or property tax. Reported coefficients can be interpreted as elasticities identified from tax reforms. All specifications include year fixed effects, municipality fixed effects, and federal-state specific year fixed effects. Columns (I) and (III) do not include controls. Columns (II) and (IV) add lagged controls for population, local GDP, level of debt, number of employees, and disposable income of private households. Note that Panel A (B) is restricted to municipalities whose business-tax multiplier is smaller (greater) than the respective property-tax multiplier. 


\section{Discussion of results}

\subsection{Comparing implemented business-tax and property-tax rates in light of relative tax elasticities}

Our empirical findings are consistent across all DiD specifications: property-tax revenue responds significantly to tax-rate changes whereas business-tax revenue does not. ${ }^{30}$ These results imply that the property-tax base is significantly less responsive than the business-tax base. Following the simple inverse-elasticity rule, this would suggest that average property taxes should be considerably higher than average business taxes. However, this is not what we observe in the data. Figure 3 depicts the evolution of the (unweighted) average business-tax multiplier and the (unweighted) average property-tax multiplier over time. The figure clearly shows that property-tax multipliers are lower than business-tax multipliers throughout our entire sample period. While the difference becomes slightly smaller over time, it has been considerably large and stable since the early 2000s.

Table A.4 in the Appendix presents more evidence in this regard. For each year between 1995 and 2010, it displays the share of municipalities which have a higher business-tax multiplier than property-tax multiplier. On average, $54 \%$ of all municipalities taxed business profits higher than property, and this share was larger than 50\% in all years except 1999 and 2000. Our results show that our main elasticity estimates are not driven by those municipalities with higher property-tax rates than business-tax rates: the business-tax elasticities are smaller even in municipalities which set higher taxes on business profits relative to those with higher property-tax rates (see Table 4).

Another perspective on comparing the tax rates of the two tax instruments is to account for the different tax bases and estimate the average tax rate on the implied 'profits' of business and property. Estimating the tax rate on business profits is simple. Recall that the BT tax rate is calculated by $\tau_{i}^{B T}=\tau_{\text {fed }}^{B T} \times m_{i}^{B T}$. Plugging in the federal rate of $3.5 \%$ and the mean LBT multiplier of $325 \%$ implies that the average local tax rate on business profits is $11.34 \%$.

Calculating the average tax on 'profits' from the property tax is slightly more complex. We aim to estimate the average real return to a property investment. We take the following approach: The mean PT multiplier is $313 \%$ and the federal

\footnotetext{
${ }^{30}$ It would be interesting to study how tax bases decline in response to higher taxes. This question is beyond the scope of our paper, but there is some first evidence in the literature with respect to business taxes: Berger et al. (2016) and Becker et al. (2012) find that incorporated firms and multinational headquarters in Germany are sensitive to local business-tax changes, respectively.
} 
rate (for West Germany) is $0.35 \% .{ }^{31}$ Recall that the tax base of the PT is the so-called standardized value of a property (Einheitswert) which is based on historic property values as of 1964 . In order to derive the PT rate on current market values of the property, information about the ratio of the 1964 values and current market values are necessary. Based on information from the German Ministry of Finance, Jorda et al. (2017) state that in 2010 the standardized values were $5 \%$ of market values (which reflects the strong increase in housing values since 1964). As a result, the average PT rate on current property market values is: $0.055 \%(=0.0035 \times$ $0.05 \times 3.13)$. The average net real return to housing in Germany is $4.12 \%$, according to Jorda et al. (2017). This then implies that the annual return to a property investment is taxed through the PT with a rate of only $1.335 \%(=0.00055 / 0.0412)$.

This back-of-the-envelope calculation is a further piece of evidence pointing in the direction that business profits are taxed higher than property 'profits'. This finding of higher BT rates is robust to the choice of the parameters in the calculation; in particular, the finding holds even for alternative plausible numbers for the annual return on property investments. ${ }^{32}$

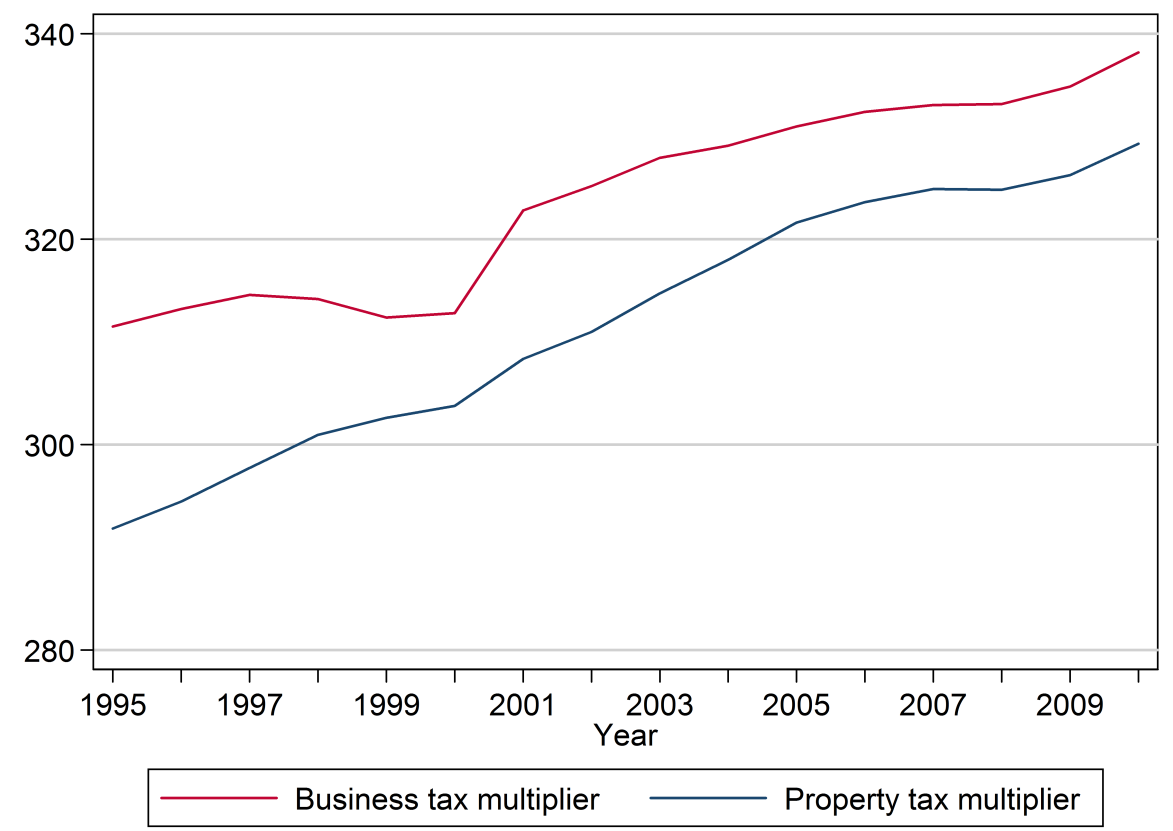

Figure 3: Average BT and PT multipliers over time

Notes: The Figure depicts the evolution of business-tax and property-tax multipliers over time. Unweighted country-wide averages for the years 1995-2010 based on municipality-level data.

Given our empirical elasticity findings, the descriptive observation that busi-

\footnotetext{
${ }^{31}$ The West-German federal rates depend on the type of property and vary between $0.26 \%$ and $0.35 \%$. We use $0.35 \%$ in our calculations as it is the most common rate. This approach hence gives us an upper bound for the tax rate. The East German rates are between 0.5 and $1 \%$.

${ }^{32}$ Using the highest federal rate of $1 \%$ for East Germany would not change the picture either.
} 
ness profits are taxed at higher rates than property stands in contrast with the inverse-elasticity rule, which depicts that goods should be taxed in inverse proportion to their tax sensitivity. Considering the simplest version of this theoretical insight, ${ }^{33}$ our baseline revenue-elasticity estimates of 0.117 for business-tax revenues and 0.668 for property-tax revenues would imply that the multiplier on property should be nearly six times higher than the multiplier on business profits. This ratio is very high and likely not feasible in practice, but it reveals that in this set-up, taxing business profits at higher rates than property is not in line with one of the basic insights of the inverse-elasticity rule. As opposed to a ratio that would be in line with this rule, we observe that in reality throughout our sample period the business-tax multiplier is on average 1.08-times higher than the property tax multiplier. In support of the claim that municipalities do not set tax rates in line with inverse-elasticity-rule ideas, we find that even those municipalities that set higher business-tax rates face highly tax-responsive business-tax bases and non-responsive property tax-bases.

\subsection{Evidence on possible explanations}

We have established two findings using our two-step strategy. First, the business-tax base is more mobile than the property-tax base in German municipalities. Second, business-tax rates are on average higher than property tax rates. In light of the first finding, this suggests that policy makers in German municipalities do not tax in accordance with the inverse-elasticity rule. The natural question that arises is: why do we find that policy-makers in German municipalities do not set tax rates according to the inverse-elasticity-rule? Several explanations come to mind that might help to rationalize our finding. This section sheds light on two possible explanations.

First, policy makers in German municipalities may have a wrong perception of the revenue effects of tax-rate changes. That is, they lack knowledge of the underlying tax-revenue elasticities (which we estimated empirically). As a result, they do not realize that it may be more efficient to tax property than business. For instance, their perceptions of the relevant elasticities depend on their political ideology. Second, tax policy might be based on political-economy arguments where politicians seek to stay in office and maximize votes. The following two subsections provide empirical evidence on both of these mechanisms on local tax policy. ${ }^{34}$

\footnotetext{
${ }^{33}$ Note that the inverse-elasticity rule reads $\tau_{1} \eta_{1}=\tau_{2} \eta_{2}$, where our estimated tax-revenue elasticities equal $\left(1+\eta_{j}\right)$, with $\eta_{j}$ being the elasticity of the tax base (see Section 4 ).

${ }^{34}$ Note that, this is, of course, not an exhaustive list of potential explanations. However, we focus on these two since they i) appear to be potentially very relevant to us and ii) we gained access to data that allow us to study these explanations. Other explanations include, for instance,
} 


\subsubsection{Politicians' beliefs about revenue elasticities}

Politicians might have a false perception/expectation of revenue elasticities. In this section, we provide some tentative evidence for this assertion, using a large-scale survey on local decision makers in the South-Western State of Baden-Württemberg (this survey was, for example, used in Janeba and Osterloh 2013). The survey allows us to shed light on revenue expectations with regard to business taxation. It does not include information about property taxation. The survey was conducted among the mayors of all 1,108 municipalities in Baden-Würtemberg in May 2008. The substantial response rate of 714 responses (64.4\%) provides a reasonable picture of mayors in the sample. Our survey question of interest is:

"What would be your assessment: By how many percent was your business tax revenue to change after three years if you were to increase the local tax multiplier from today's level by 50 points?".35

The respondents can give seven different evaluations of tax-revenue elasticities using the following discrete categories: $-10 \%,-10$ to $-5 \%,-5$ to $0 \%$, no change, 0 to $5 \%, 5$ to $10 \%$ and above $10 \%$.

Hence, the survey does not provide a continuous measure of the revenue elasticity of local profit taxes (as estimated in our empirical analysis above) but rather hints at the respondents' general beliefs whether there will be positive or negative revenue effects triggered by a significant tax rate increase and in what range that change might probably come about.

Figure 4 provides an illustration of perceived tax rate elasticities of business tax revenues in our survey sample. More than $60 \%$ of local politicians in the sample think that a tax rate increase of the local business tax will increase their revenues. This implies that most politicians in our sample believe that firm profits - the tax base of local business tax - are rather immobile and that higher business-tax profits can substantially increase revenues. This is somewhat in contrast with our empirical findings which indicate that a tax increase does not significantly affect revenues. $17.5 \%$ of respondents believe that the surveyed increase does not have an effect on revenues. These expectations are in accordance with our findings. Roughly

distributional/social-policy concerns. Fairness and equity considerations are widely discussed in the context of tax progressivity of non-linear taxes (Diamond and Saez 2011; Saez and Stantcheva 2017). For instance, Kuziemko et al. (2015) show that information about inequality raises the public support for higher estate and top income tax rates. In our context, politicians might want to set low property taxes to encourage individuals to own property and buy real-estate.

${ }^{35}$ Such an increase in absolute tax rate multipliers corresponds to a $15.4 \%$ increase for the average German municipality in 2008 when evaluated at the respective sample mean. 
$20 \%$ of all respondents think that an increase of the local business tax will lead to a decline of their tax revenues. This is against our findings (with a non-significant positive coefficient) but possibly informed by an earlier study by Buettner (2003) who finds negative revenue effects of higher taxes.

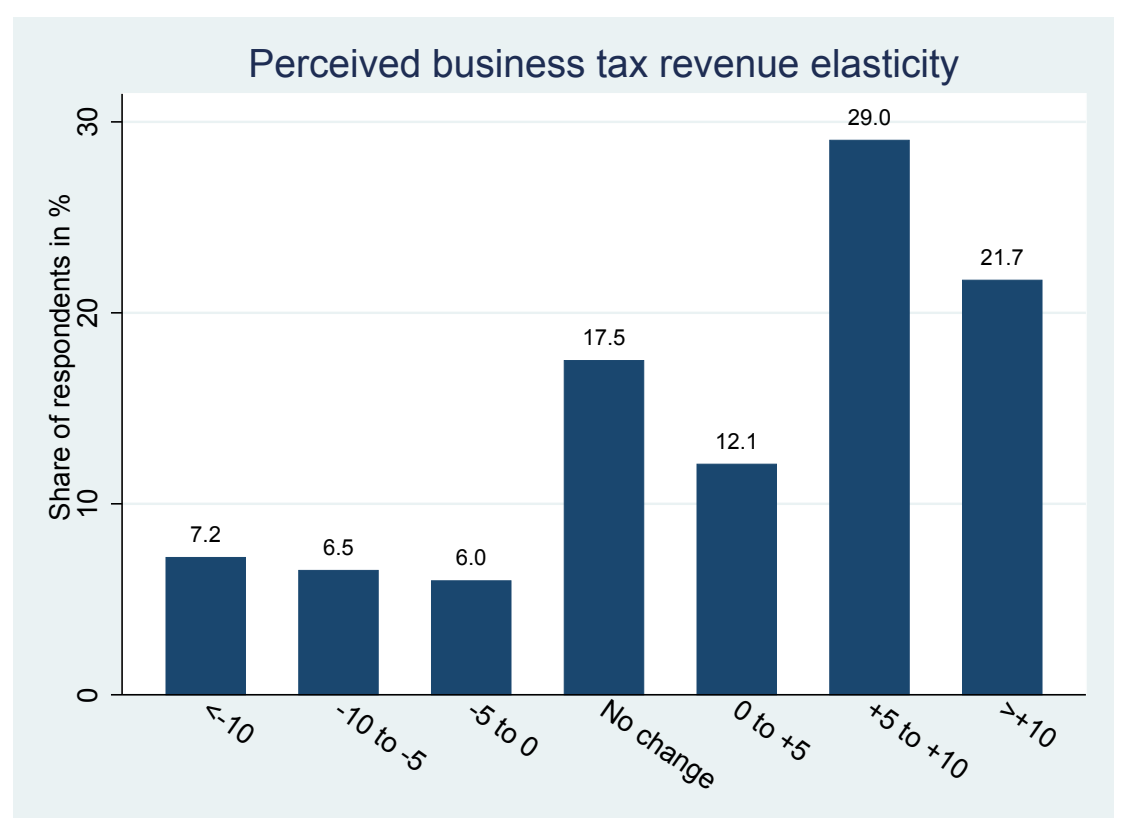

Figure 4: Distribution of perceived business tax revenue elasticities Source: Survey data are taken from Janeba and Osterloh (2013).

This corresponds with evidence from two additional questions from the survey illustrated in Figure A.4 in the Appendix, illustrating the degree of perceived importance of the business tax rate for firm location (Panel (a)) as well as the perceived prevalence of profit shifting across municipal borders as a response to tax rate changes on firm profits (Panel (b)). Panel (a) of Figure A.4 indicates that local politicians think that the business tax rate has a positive but only marginal effect for attracting firms to the community (centered around +1 responses). Panel (b) of Figure A.4 indicates that the vast majority of respondents believe that firms might engage somewhat in profit shifting but not to a large degree. This is evidence that local politicians are aware of tax-competition concerns but they, however, somewhat overestimate the revenue returns from increasing tax rates on firm profits.

What are the drivers behind beliefs about revenue elasticities? In order to shed light on this, we apply two sets of analyses. ${ }^{36}$ First, we study the role of political ideology for revenue beliefs. To do so, we run an ordered probit regression using the

\footnotetext{
${ }^{36}$ Results are available on request.
} 
survey question about revenue elasticities that we reported before (i.e. the same that is used in Figure 4). We regress the answers to this questions on a set of variables including a variable for the share of left-leaning political parties (or alternatively, left majorities) in the respective municipal council. We find that incumbents from left-majoritarian towns believe significantly more (less) in high positive (negative) revenue elasticities. This result is robust to the inclusion of a variety of several other town-level characteristics. This finding corresponds with literature that identifies political ideology to be a dominant driver of tax rate choices (Heinemann and Janeba 2011; Ashworth and Heyndels 1997; Janeba 2014; Janeba et al. 2017). These studies commonly find that left-leaning politicians (or individuals) choose higher tax rates. ${ }^{37}$ Moreover, our findings are in line with the results of Heinemann and Janeba (2011) who find left-leaning politicians to exert stronger beliefs in low capital mobility. ${ }^{38}$

Second, we aim to analyze the effect of political experience on expectations regarding revenue elasticities of the respondents. Given data restrictions, we can perform the respective analysis only on a smaller sub-sample of 294 respondents. ${ }^{39}$ Ordered probit models suggest that political experience does not affect beliefs on revenue effects of business tax hikes. Note that, possibly due to data restrictions we cannot identify effects of (the lack of) economic knowledge or education on elasticity expectations for the local business tax in our sample. However, that does not necessarily mean that such an mechanism does not exist. ${ }^{40}$

Our survey evidence suggests that local decision makers tend to underestimate (overstate) business profit mobility (revenue effects) from tax increases as compared to non-significant effects in our empirical results. We cannot find differences due to advantageous political or economic information of our respondents. However, expectations on mobility or tax revenue elasticities for the business tax might be driven by party ideology with left-leaning politicians believing in stronger revenue gains from tax hikes. Hence, local politics might have an incentive to increase

\footnotetext{
${ }^{37}$ Freier and Odendahl (2015), however, find that centre-left parties tend to decrease tax rates and the Greens to even increase property tax rates.

${ }^{38}$ Our findings further indicate that mayors that are directly elected representatives are more pessimistic about large revenue gains from tax rate hikes of the business tax as compared to bureaucrats from local budget offices.

${ }^{39}$ We hand-collected personal information on politicians in our survey but only a fraction of $49 \%$ survey respondents explicitly stated that they are mayors, most others said that they are in fact local clerks in the local budget office. We gathered data on age, years in office, party affiliation, having a doctoral degree and job type of mayor, i.e. being a full-time mayor or being on a parttime mayor position. These data are only available for most mayors (294 out of 365), not for respondents that stated to be bureaucrats from the local budget offices (381 individuals).

${ }^{40}$ Heinemann and Janeba (2011), however, found information background such as years in parliament, professional background (being self-employed) or financial committee membership to be significant for German national politicians' beliefs on international mobility of paper profits.
} 
business tax rate more than optimal in order to increase tax revenues. This might be especially true since business tax revenues are on average more than three times as high as property tax revenues (see Table 1). Unfortunately, our survey does not allow us to make inference on revenue expectations from property tax changes.

\subsubsection{Political economy reasons}

The second assertion that we investigate is whether political-economy incentives are the actual drivers of tax policy. That is, we test if tax rates are set depending on strategic political behavior rather than depending on economic efficiency arguments. To do so, we study the effects of elections on tax-rate setting in German municipalities. That is, we study if tax setting behavior depends on the electoral cycle, i.e. via differences in political budget cycles (e.g., Persson and Tabellini 1990). Policy makers might use the policy tools of business and property taxes in alternate ways around election dates to send signals (i.e., competency, ability to 'act', tax gifts) and to stay in office.

We investigate differences in electoral cycles between the growth rates of business tax and property rates by replicating the analysis of Foremny and Riedel (2014) using our sample of all German municipalities in the period 1995-2010. ${ }^{41}$ Despite having a larger sample including East Germany, a further difference to Foremny and Riedel (2014) is that we study the electoral effects on business and property taxes, while Foremny and Riedel (2014) focus on business taxes only. Identifying variation comes from election dates of municipal councils which vary across federal states and are fixed by the respective federal state's constitution. This gives rise to a DiD design in a fixed effects framework.

Specifically, we regress the yearly growth rates of either business and property tax rates on dummies of election dates as well their respective leads and lags. We control for municipality fixed effects and year fixed effects and account for timevarying municipality and county characteristics (as we do in our main regressions; see Section 4).

Models (I) and (II) of Table 5 show the results for specifications with and without control variables. The coefficients depict the effect of election years, the year before an election and the year after an election growth rates of tax rates, always relative to the development of growth rates in municipalities that do not have an election year (or are not in a year before an election or in a year afterward). The results indicate that local politicians lower both business and property tax rates

\footnotetext{
${ }^{41}$ Our sample is larger than the sample of Foremny and Riedel (2014) as we include East Germany and have a longer panel. Using their sample of West-German municipalities in 2002-2008, we yield very similar results for the business tax rate growth rates.
} 
in the election year and the year before an election, where the effect is largest (in absolute amounts) in the election year.

However, there are differences in election effects for business and property taxes. First, growth rates of property taxes are decreased by more than twice as much as growth rates of the business tax rate in the election year. Second, although being decreased in the year prior to council elections, business tax rates are relatively increased in the aftermath of municipal elections (see Model (II); this is similar to Foremny and Riedel 2014), whereas property tax rates are even slightly decreased, relatively, after the election.

Larger property tax effects in the election year might be due to a higher salience and visibility of property taxes in Germany compared to the business tax. For instance, Löffler and Siegloch (2015) show that not only house owners pay for the property tax but in the medium run the economic incidence is fully shifted to tenants. Politicians' calculus might be that property taxes affect more people in the municipality than business taxes, hence being a better instrument to gain more votes; business tax is only paid by an arguably smaller group of (incorporated) business owners which might not even necessarily live in the municipality's jurisdiction. 
Table 5: Electoral cycles in business and property taxation, tax growth rates

\begin{tabular}{lcccc}
\hline & \multicolumn{2}{c}{$(\mathrm{I})$} & \multicolumn{2}{c}{$(\mathrm{II})$} \\
& $\mathrm{BT}$ & $\mathrm{PT}$ & $\mathrm{BT}$ & $\mathrm{PT}$ \\
\hline Election $_{t-1}$ & $-0.111^{* * *}$ & $-0.071^{* *}$ & $-0.099^{* * *}$ & $-0.065^{*}$ \\
& $(0.024)$ & $(0.033)$ & $(0.023)$ & $(0.034)$ \\
Election & $-0.246^{* * *}$ & $-0.542^{* * *}$ & $-0.209^{* * *}$ & $-0.531^{* * *}$ \\
& $(0.023)$ & $(0.029)$ & $(0.021)$ & $(0.030)$ \\
Election $_{t+1}$ & $-0.045^{*}$ & $-0.144^{* * *}$ & $0.073^{* * *}$ & $-0.070^{*}$ \\
& $(0.023)$ & $(0.037)$ & $(0.024)$ & $(0.039)$ \\
Year FE & yes & yes & yes & yes \\
Municip. FE & yes & yes & yes & yes \\
Controls & no & no & yes & yes \\
N & 131,891 & 117,999 & 112,072 & 100,891 \\
\hline
\end{tabular}

Notes: Dependent variable is the yearly growth rate of business tax rates (depicted in BT columns) or the yearly growth rate of property tax rates (depicted in PT columns). Fixed-effects regressions based on Foremny and Riedel (2014) with standard errors in parentheses. Robust standard errors are clustered on the municipality level. Significance levels are ${ }^{*}<0.10,{ }^{* *}<0.05,{ }^{* * *}<0.01$. Coefficients for the pre-election, election, and post-election year are reported in Model (I) and (II). Election dates across states in the sample period are taken from the statistical offices of the German states. Administrative data on all German municipalities (except for German city states due to comparability issues) in 1995-2010. The unit of observation is a single municipality. All specifications include year fixed effects, and municipality fixed effects. Model (II) includes controls for population, local GDP, level of debt, number of employees, and disposable private income.

\section{Conclusion}

Using rich panel data on the universe of German municipalities between 1995 and 2010, this paper estimates how tax revenue generated from business and property taxes responds to variation in the respective tax rates. We use two different estimation strategies to do this, an event-study design and a generalized DiD. Both approaches yield similar results and indicate that property tax revenues increase significantly and substantially after an increase in property taxes. In contrast, we find small insignificant effects for the effects of business taxes on business-tax revenues. This implies that business profits are rather tax sensitive whereas property does not respond significantly in the short-run. Applying basic intuition based on the inverse-elasticity rule, these elasticity estimates would suggest that average tax rates are significantly higher on property relative to business-tax rates. However, this is not what we observe in the data: on average, property values are consistently taxed at lower rates than business profits. This suggests that actual local taxation in Germany is inconsistent with the inverse-elasticity rule.

We provide some suggestive evidence and test two channels due to which mu- 
nicipalities would likely deviate from tax policies based on Ramsey results. We find that higher business tax rates might accrue both to politician's exaggerated expectations about tax-revenue elasticities (partly due to political ideology) and lower decreases of business tax rate growth along the electoral cycle, i.e. heterogeneous importance of tax instruments to politician's re-election concerns. However, in line with the argumentation of Mankiw et al. (2009), more empirical work is needed to learn whether real-world taxation complies with rules from optimal taxation.

\section{References}

Angrist, J. D. and J.-S. Pischke (2009). Mostly harmless econometrics: An empiricistvs companion. Princeton Univ Pr.

Arnold, F., F. Boettcher, R. Freier, R. Geißler, and B. Holler (2015). Kommunaler finanzreport 2015. BertelsmannStiftung, Gütersloh.

Ashworth, J. and B. Heyndels (1997). Politicians' preferences on local tax rates: an empirical analysis. European Journal of Political Economy 13(3), 479-502.

Baskaran, T. (2014). Identifying local tax mimicking with administrative borders and a policy reform. Journal of Public Economics 118, 41 - 51.

Baskaran, T. (2015). The revenue and base effects of local tax hikes: Evidence from a quasi-experiment. Center for European, Governance and Economic Development Research (cege) Discussion Paper 257.

Baumol, W. J. and D. F. Bradford (1970, June). Optimal Departures from Marginal Cost Pricing. American Economic Review 60(3), 265-83.

Becker, S. O., P. H. Egger, and V. Merlo (2012). How low business tax rates attract MNE activity: Municipality-level evidence from Germany. Journal of Public Economics 96(9-10), 698-711.

Berger, M., F. Misch, and J. Voget (2016). Becoming an entrepreneur-the role of profit taxes.

Brill, A. and K. A. Hassett (2007). Revenue-maximizing corporate income taxes: The laffer curve in oecd countries. AEI working paper no. 137.

Buettner, T. (2003). Tax base effects and fiscal externalities of local capital taxation: evidence from a panel of German jurisdictions. Journal of Urban Economics 54(1), 110-128.

Castanheira, M., G. Nicodeme, and P. Profeta (2012). On the political economics of tax reforms: survey and empirical assessment. International Tax and Public Finance 19(4), 598-624. 
Clausing, K. (2007). Corporate tax revenues in OECD countries. International Tax and Public Finance 14(2), 115-133.

Creedy, J. and N. Gemell (2015). Measuring revenue-maximizing elasticities of taxable income: Evidence for the us income tax. Victoria university of wellington working paper in public finance 02 .

Dahlby, B. and E. Ferede (2012). The effects of tax rate changes on tax bases and the marginal cost of public funds for Canadian provincial governments. International Tax and Public Finance 19(6), 844-883.

de Mooij, R. and G. Nicodeme (2008). Corporate tax policy and incorporation in the EU. International Tax and Public Finance 15(4), 478-498.

Devereux, M., L. Liu, and S. Loretz (2014). The elasticity of corporate taxable income: New evidence from UK tax records. American Economic Journal: Economic Policy 6(2), 19-53.

Devereux, M. P. (2007). Developments in the taxation of corporate profit in the oecd since 1965: Rates, bases and revenues. Working Papers 07/04, Oxford University Centre for Business Taxation.

Devereux, M. P. and R. Griffith (1998). Taxes and the location of production: evidence from a panel of US multinationals. Journal of Public Economics 68(3), $335-367$.

Diamond, P. and E. Saez (2011). The case for a progressive tax: From basic research to policy recommendations. Journal of Economic Perspectives 25(4), 165-90.

Diamond, P. A. and J. A. Mirrlees (1971). Optimal taxation and public production i: Production efficiency. The American Economic Review 61(1), 8-27.

Dwenger, N. and V. Steiner (2012). Profit taxation and the elasticity of the corporate income tax base: Evidence from German corporate tax return data. National Tax Journal 65(1), 118-50.

Feld, L. P. and J. H. Heckemeyer (2011). FDI and taxation: A meta-study. Journal of Economic Surveys 25(2), 233-272.

Foremny, D. and N. Riedel (2014). Business taxes and the electoral cycle. Journal of Public Economics 115, 48 - 61.

Fossen, F. M. and V. Steiner (2014). The tax-rate elasticity of local business profits. DIW Discussion Paper 1424.

Freier, R. and C. Odendahl (2015). Do parties matter? estimating the effect of 
political power in multi-party systems. European Economic Review 80, 310328.

Fuest, C., A. Peichl, and S. Siegloch (2017). Do higher corporate taxes reduce wages? Micro evidence from Germany. American Economic Review forthcoming.

Graham, J. R. (2003). Taxes and corporate finance: A review. Review of Financial Studies 16(4), 1075-1129.

Gruber, J. and J. Rauh (2007). How elastic is the corporate income tax base? In A. J. Auerbach, J. R. H. Jr., and J. B. Slemrod (Eds.), Taxing Corporate Income in the 21st Century, pp. 140-163. Cambirdge, MA: Cambridge University Press.

Heinemann, F. and E. Janeba (2011). Viewing tax policy through party-colored glasses: What german politicians believe. German Economic Review 12(3), $286-311$.

Isen, A. (2014). Do local government fiscal spillovers exist? evidence from counties, municipalities, and school districts. Journal of Public Economics 110, 57 -73 .

Janeba, E. (2014). Tax policy, tax competition, and fiscal rules: Insights from a classroom experiment and surveys of politicians. FinanzArchiv: Public Finance Analysis 70(3), 345-373.

Janeba, E., D. Engelmann, L. Mechtenberg, and N. Wehrhöfer (2017). Preferences over taxation of high income individuals: Evidence from online and laboratory experiments.

Janeba, E. and S. Osterloh (2013). Tax and the cityâa theory of local tax competition. Journal of Public Economics 106, 89-100.

Jorda, O., K. Knol, M. Schularick, D. Kuvshinov, and A. Taylor (2017). The rate of return on everything, 1870-2015. CEPR discussion paper12509.

Kawano, L. and J. Slemrod (2015). How do corporate tax bases change when corporate tax rates change? With implications for the tax rate elasticity of corporate tax revenues. International Tax and Public Finance, 1-33.

Kuziemko, I., M. I. Norton, E. Saez, and S. Stantcheva (2015). How elastic are preferences for redistribution? evidence from randomized survey experiments. The American Economic Review 105(4), 1478-1508.

Landkreistag, D. (2017). Berechnung der steuerkraftmesszahl der gemeinden 2016/2017. http://www.kreise.de/__cms1/images/stories/themen/ 
Kreisfinanzen/grafiken2016/grafiken_2017/Tab._6_Berechnung_der_ Steuerkraftmesszahl_der_Gemeinden.pdf/. Accessed: 2017-12-21.

Löffler, M. and S. Siegloch (2015). Property taxation, local labor markets and rental housing.

Lyytikäinen, T. (2012). Tax competition among local governments: Evidence from a property tax reform in finland. Journal of Public Economics 96 (7), 584-595.

Mankiw, N., M. Weinzierl, and D. Yagan (2009). Optimal taxation in theory and practice. Journal of Economic Perspectives 23, 147-174.

Mintz, J. and M. Smart (2004). Income shifting, investment, and tax competition: theory and evidence from provincial taxation in Canada. Journal of Public Economics 88(6), 1149-1168.

Persson, T. and G. E. Tabellini (1990). Macroeconomic policy, credibility and politics, Volume 38. Taylor \& Francis.

Piketty, T. and E. Saez (2013). Chapter 7 - optimal labor income taxation. In M. F. Alan J. Auerbach, Raj Chetty and E. Saez (Eds.), Handbook of Public Economics, vol. 5, Volume 5 of Handbook of Public Economics, pp. 391 - 474. Elsevier.

Ramsey, F. P. (1927). A contribution to the theory of taxation. The Economic Journal 37(145), $47-61$.

Saez, E. (2001). Using elasticities to derive optimal income tax rates. The Review of Economic Studies 68(1), 205-229.

Saez, E., J. Slemrod, and S. H. Giertz (2012). The elasticity of taxable income with respect to marginal tax rates: A critical review. Journal of Economic Literature 50(1), 3-50.

Saez, E. and S. Stantcheva (2017). A simpler theory of optimal capital taxation. Journal of Public Economics.

Simon, D. (2016). Does early life exposure to cigarette smoke permanently harm childhood welfare? evidence from cigarette tax hikes. American Economic Journal: Applied Economics 8(4), 128-159.

Sørensen, P. B. (2007). The theory of optimal taxation: what is the policy relevance? International Tax and Public Finance 14(4), 383-406.

Stine, W. (1988). Estimating property tax base elasticity over time: Evidence on the revenue maximizing politician. Public Choice 58(1), 35-44. 


\section{Appendix}

\section{A Summary statistics}

Table A.1: Number of observations by year, 1995- 2010

\begin{tabular}{cr}
\hline Year & $\mathbf{N}$ \\
\hline 1995 & 8980 \\
1996 & 8964 \\
1997 & 8956 \\
1998 & 9507 \\
1999 & 10522 \\
2000 & 10551 \\
2001 & 12363 \\
2002 & 11890 \\
2003 & 11622 \\
2004 & 11654 \\
2005 & 11693 \\
2006 & 11874 \\
2007 & 11935 \\
2008 & 11605 \\
2009 & 11470 \\
2010 & 11084 \\
Total & 174670
\end{tabular}

Notes: Number of municipalities in each year for which data are available. Administrative data on the universe of German municipalities. Baseline sample: Years 1995 to 2010. Restricted to observations for which information on BT and PT were available. Observation excluded if revenue is reported negative. 
Table A.2: Size of changes in BT multipliers, 1995- 2010

\begin{tabular}{lrrrrrrrrr}
\hline \hline Year & I & II & III & IV & V & VI & VII & VIII & IX \\
1995 & 0.03 & 0.09 & 0.50 & 0.10 & 85.60 & 5.35 & 7.85 & 0.46 & 0.03 \\
1996 & 0.04 & 0.14 & 0.43 & 0.18 & 91.55 & 2.82 & 4.45 & 0.38 & 0.01 \\
1997 & 0.04 & 0.15 & 0.33 & 0.20 & 91.17 & 2.33 & 5.40 & 0.32 & 0.05 \\
1998 & 0.01 & 0.13 & 0.28 & 0.19 & 91.04 & 3.16 & 4.75 & 0.39 & 0.05 \\
1999 & 0.06 & 0.14 & 0.48 & 0.25 & 95.37 & 1.37 & 2.14 & 0.18 & 0.00 \\
2000 & 0.07 & 0.16 & 0.43 & 0.28 & 94.98 & 1.61 & 2.21 & 0.24 & 0.02 \\
2001 & 0.01 & 0.10 & 0.44 & 0.30 & 91.99 & 3.65 & 3.11 & 0.34 & 0.06 \\
2002 & 0.04 & 0.11 & 0.27 & 0.24 & 92.04 & 2.98 & 4.04 & 0.28 & 0.01 \\
2003 & 0.03 & 0.04 & 0.22 & 0.30 & 90.31 & 2.72 & 6.14 & 0.22 & 0.02 \\
2004 & 0.04 & 0.07 & 0.30 & 0.24 & 91.19 & 3.06 & 4.84 & 0.22 & 0.05 \\
2005 & 0.02 & 0.07 & 0.33 & 0.28 & 88.88 & 4.16 & 5.96 & 0.29 & 0.01 \\
2006 & 0.03 & 0.04 & 0.42 & 0.37 & 91.80 & 3.91 & 3.12 & 0.25 & 0.06 \\
2007 & 0.02 & 0.04 & 0.40 & 0.38 & 95.50 & 1.69 & 1.78 & 0.15 & 0.04 \\
2008 & 0.00 & 0.09 & 0.45 & 0.32 & 95.71 & 1.12 & 1.88 & 0.40 & 0.03 \\
2009 & 0.00 & 0.05 & 0.57 & 0.50 & 95.16 & 1.11 & 2.28 & 0.30 & 0.03 \\
2010 & 0.03 & 0.04 & 0.30 & 0.48 & 90.21 & 2.29 & 5.82 & 0.80 & 0.04 \\
Total & 0.03 & 0.09 & 0.38 & 0.30 & 92.18 & 2.65 & 4.02 & 0.32 & 0.03 \\
\hline \hline
\end{tabular}

Notes: Share of municipalities which change their business-tax multiplier in the range of the following nine categories, I - IX, by year. I: $<-100$; II: $-100 \leq$ change $<-50$; III: $-50 \leq$ change $<-10$; IV : $-10 \leq$ change $<0$; V: no change; VI: $0<$ change $\leq 10$; VII: $10<$ change $\leq 50$; VIII: $50<$ change $\leq 100$; IX: change $>100$. Municipal level variable. Administrative data on the universe of German municipalities. Baseline sample: Years 1995 to 2010. Restricted to observations for which information on BT and PT were available. Observation excluded if revenue is reported negative. 
Table A.3: Size of changes in PT multipliers, 1995- 2010

\begin{tabular}{lrrrrrrrrr}
\hline \hline Year & I & II & III & IV & V & VI & VII & VIII & IX \\
1995 & 0.00 & 0.10 & 0.22 & 0.04 & 81.03 & 3.44 & 13.99 & 1.07 & 0.10 \\
1996 & 0.00 & 0.11 & 0.20 & 0.10 & 89.40 & 2.15 & 7.49 & 0.56 & 0.00 \\
1997 & 0.00 & 0.04 & 0.24 & 0.21 & 87.06 & 2.56 & 9.09 & 0.80 & 0.01 \\
1998 & 0.01 & 0.05 & 0.20 & 0.14 & 87.60 & 3.03 & 8.35 & 0.56 & 0.05 \\
1999 & 0.01 & 0.04 & 0.21 & 0.16 & 93.75 & 1.57 & 4.05 & 0.18 & 0.03 \\
2000 & 0.00 & 0.07 & 0.34 & 0.13 & 94.05 & 1.37 & 3.90 & 0.14 & 0.01 \\
2001 & 0.00 & 0.26 & 0.28 & 0.20 & 91.70 & 3.45 & 3.82 & 0.25 & 0.02 \\
2002 & 0.01 & 0.02 & 0.15 & 0.12 & 90.03 & 2.35 & 6.62 & 0.66 & 0.04 \\
2003 & 0.01 & 0.03 & 0.12 & 0.07 & 86.65 & 2.17 & 8.72 & 2.15 & 0.07 \\
2004 & 0.00 & 0.00 & 0.15 & 0.13 & 86.74 & 2.57 & 9.62 & 0.79 & 0.02 \\
2005 & 0.00 & 0.03 & 0.13 & 0.15 & 85.02 & 3.53 & 10.34 & 0.77 & 0.04 \\
2006 & 0.05 & 0.04 & 0.13 & 0.19 & 90.02 & 2.62 & 6.38 & 0.50 & 0.07 \\
2007 & 0.01 & 0.03 & 0.33 & 0.23 & 94.30 & 1.28 & 3.51 & 0.28 & 0.03 \\
2008 & 0.01 & 0.08 & 0.53 & 0.30 & 95.00 & 1.20 & 2.68 & 0.18 & 0.01 \\
2009 & 0.01 & 0.11 & 0.51 & 0.44 & 94.93 & 1.00 & 2.80 & 0.19 & 0.03 \\
2010 & 0.02 & 0.05 & 0.26 & 0.51 & 87.12 & 2.16 & 8.64 & 1.11 & 0.12 \\
Total & 0.01 & 0.06 & 0.25 & 0.20 & 89.86 & 2.23 & 6.71 & 0.64 & 0.04 \\
\hline \hline
\end{tabular}

Notes: Share of municipalities which change their property-tax multiplier in the range of the following nine categories, I - IX, by year. I: $<-100$; II: $-100 \leq$ change $<-50$; III: $-50 \leq$ change $<-10$; IV : $-10 \leq$ change $<0$; V: no change; VI: $0<$ change $\leq 10$; VII: $10<$ change $\leq 50$; VIII: $50<$ change $\leq 100$; IX: change $>100$. Municipal level variable. Administrative data on the universe of German municipalities. Baseline sample: Years 1995 to 2010. Restricted to observations for which information on BT and PT were available. Observation excluded if revenue is reported negative. 
Table A.4: Share of municipalities with higher tax rates on BT than PT by year

\begin{tabular}{cr}
\hline Year & Mean \\
\hline 1995 & 0.567 \\
1996 & 0.565 \\
1997 & 0.555 \\
1998 & 0.513 \\
1999 & 0.472 \\
2000 & 0.468 \\
2001 & 0.574 \\
2002 & 0.582 \\
2003 & 0.582 \\
2004 & 0.562 \\
2005 & 0.546 \\
2006 & 0.539 \\
2007 & 0.534 \\
2008 & 0.532 \\
2009 & 0.537 \\
2010 & 0.547 \\
\hline Total & 0.543 \\
\hline \hline
\end{tabular}

Notes: The table depicts for each year the share of municipalities that have a higher multiplier on business-profits than on propety. Municipal level variables. Administrative data on the universe of German municipalities. Baseline sample: Years 1995 to 2010. Restricted to observations for which information on BT and PT were available. Observation excluded if revenue is reported negative. 



Figure A.1: BT (left) and PT (right) multipliers in 2001

Notes: The Figure depicts the spatial distribution and levels of business-tax (left) and property-tax (right) multipliers in 2001. Own compilation with geoinformation provided by the GeoDataCenter (Federal Agency for Cartography and Geodesy).
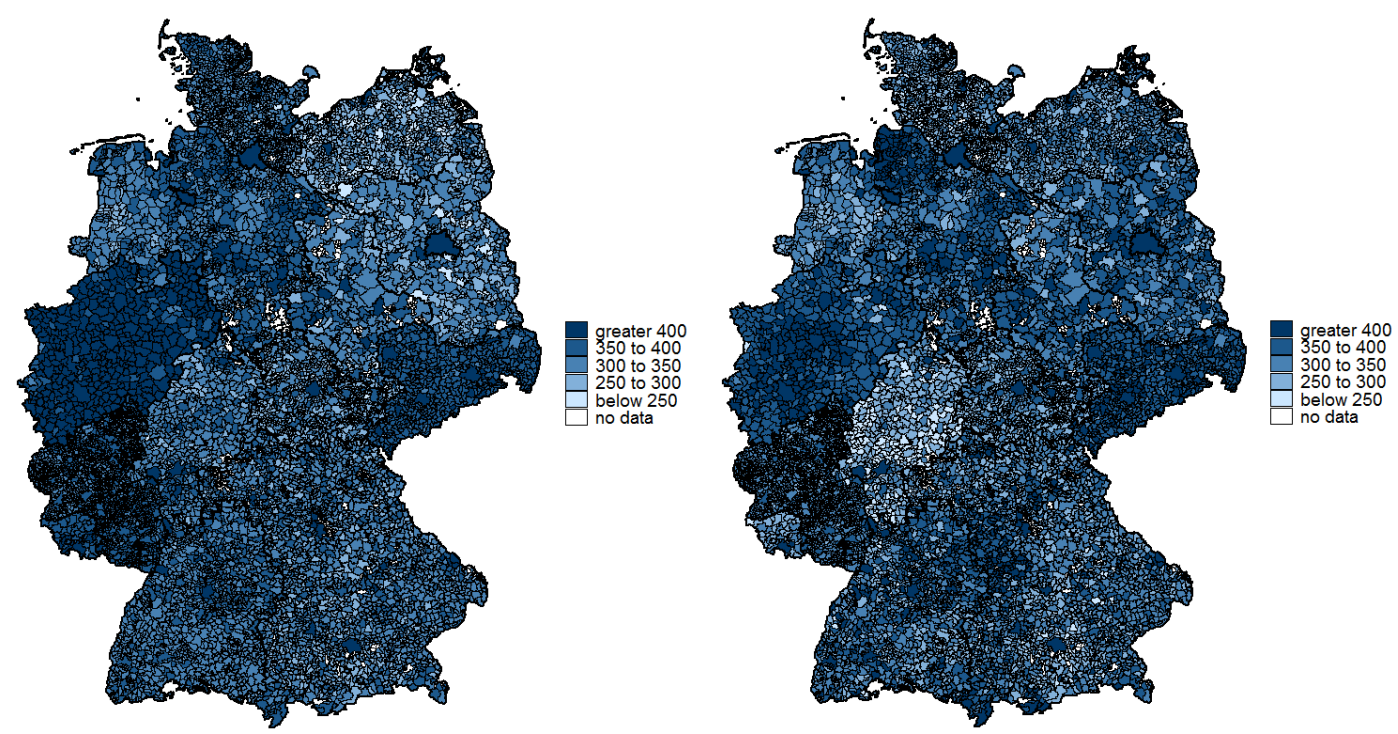

Figure A.2: BT (left) and PT (right) multipliers in 2010

Notes: The Figure depicts the spatial distribution and levels of business-tax (left) and property-tax (right) multipliers in 2010. Own compilation with geoinformation provided by the GeoDataCenter (Federal Agency for Cartography and Geodesy). 


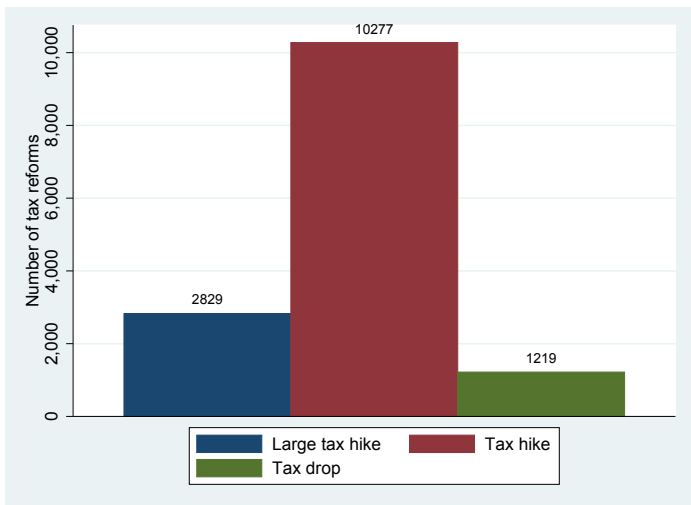

(a) Business tax

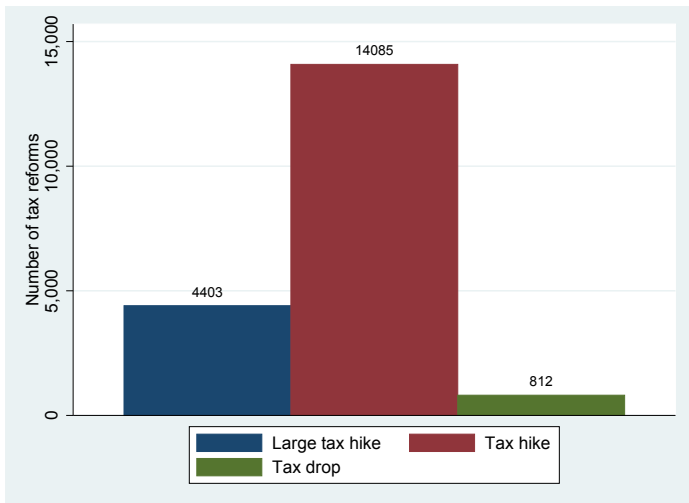

(b) Property tax

Figure A.3: Frequency of reform types for BT and PT in 1995-2010

Notes: Number of tax reforms per reform category in business tax (Panel (a)) and property tax (Panel (b)). Reform categories are tax increase, large tax increase (greater than or equal to the 75th percentile of the tax increase distribution), or a tax decrease (see legend).

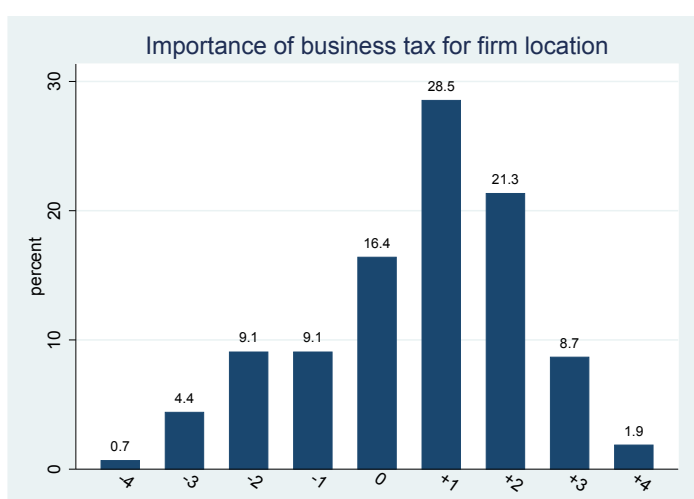

(a) Importance for firm location

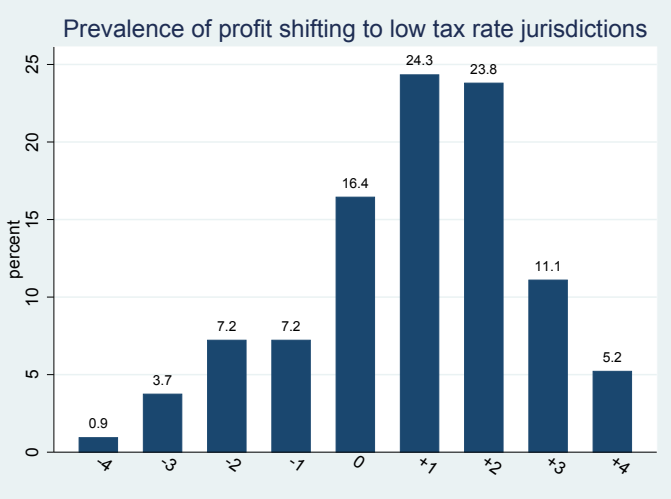

(b) Prevalence of profit shifting

Figure A.4: Beliefs on business tax rate effects

Source: Survey data are taken from Janeba and Osterloh (2013).

Panel (a) question reads "The rate of the local business tax is said to be a motive to be considered for firms when making their location choice. How important do you think is the size of the local business tax rate for a firm's location choice?". Respondents can chose answers ranging from entirely unimportant (-4) to very important (4). Panel (b) question reads "Companies presumably use tax planning instruments to relocate "paper" profits from high-tax to low-tax municipalities. How widespread do you think is this phenomenon?". Respondents can chose answers ranging from not widespread at all (-4) to very widespread (4). 


\section{B Robustness checks}

Table B.1: Robustness checks: Sample variations

\begin{tabular}{|c|c|c|c|c|}
\hline & (I) & (II) & (III) & $(\mathrm{IV})$ \\
\hline & \multicolumn{2}{|c|}{ Tax revenue business } & \multicolumn{2}{|c|}{ Tax revenue property } \\
\hline \multicolumn{5}{|c|}{ Panel A: Balanced Panel } \\
\hline \multirow[t]{2}{*}{$m_{t-1}^{B T}$} & 0.130 & 0.122 & & \\
\hline & $(0.127)$ & $(0.124)$ & & \\
\hline \multirow[t]{2}{*}{$m_{t-1}^{P T}$} & & & $0.695^{* * *}$ & $0.695^{* * *}$ \\
\hline & & & $(0.012)$ & $(0.012)$ \\
\hline $\mathrm{N}$ & 74,760 & 73,172 & 74,760 & 73,172 \\
\hline$R^{2}$ & 0.203 & 0.194 & 0.753 & 0.772 \\
\hline \multicolumn{5}{|c|}{ Panel B: No Overlap of Reform Years in BT and PT } \\
\hline \multirow{2}{*}{$m_{t-1}^{B T}$} & $0.172^{*}$ & 0.155 & & \\
\hline & $(0.094)$ & $(0.098)$ & & \\
\hline \multirow[t]{2}{*}{$m_{t-1}^{P T}$} & & & $0.642^{* * *}$ & $0.653^{* * *}$ \\
\hline & & & $(0.012)$ & $(0.011)$ \\
\hline $\mathrm{N}$ & 120,637 & 105,828 & 123,566 & 108,682 \\
\hline$R^{2}$ & 0.148 & 0.155 & 0.557 & 0.623 \\
\hline
\end{tabular}

Notes: Fixed-effects regressions based on equation $((2))$ with standard errors in parentheses. Robust standard errors clustered on the municipality level. Significance levels are ${ }^{*}<0.10,{ }^{* *}<0.05$, *** $<0.01$. Administrative data on the universe of German municipalities. Years in baseline: 1995 to 2010. The dependent variable in columns (I) and (II) is municipality-level tax revenue generated from the local business tax (BT), and municipality-level tax revenue from the local property tax (PT) in columns (III) and (IV). The independent variable of interest is the municipality-level tax multiplier in $t-1$. Reported coefficients can be interpreted as elasticities identified from tax reforms. All specifications include year fixed effects, municipality fixed effects, and federal-state specific fixed effects. Columns (I) and (III) do not include controls. Columns (II) and (IV) add lagged controls for population, local GDP, level of debt, number of employees, and private income. Panel A is identical to the baseline results in Table 3 but estimated on a balanced sample of municipalities. Panel B cuts observations from the unbalanced panel in which there are reforms in both the business and property tax rates in a given municipality. 


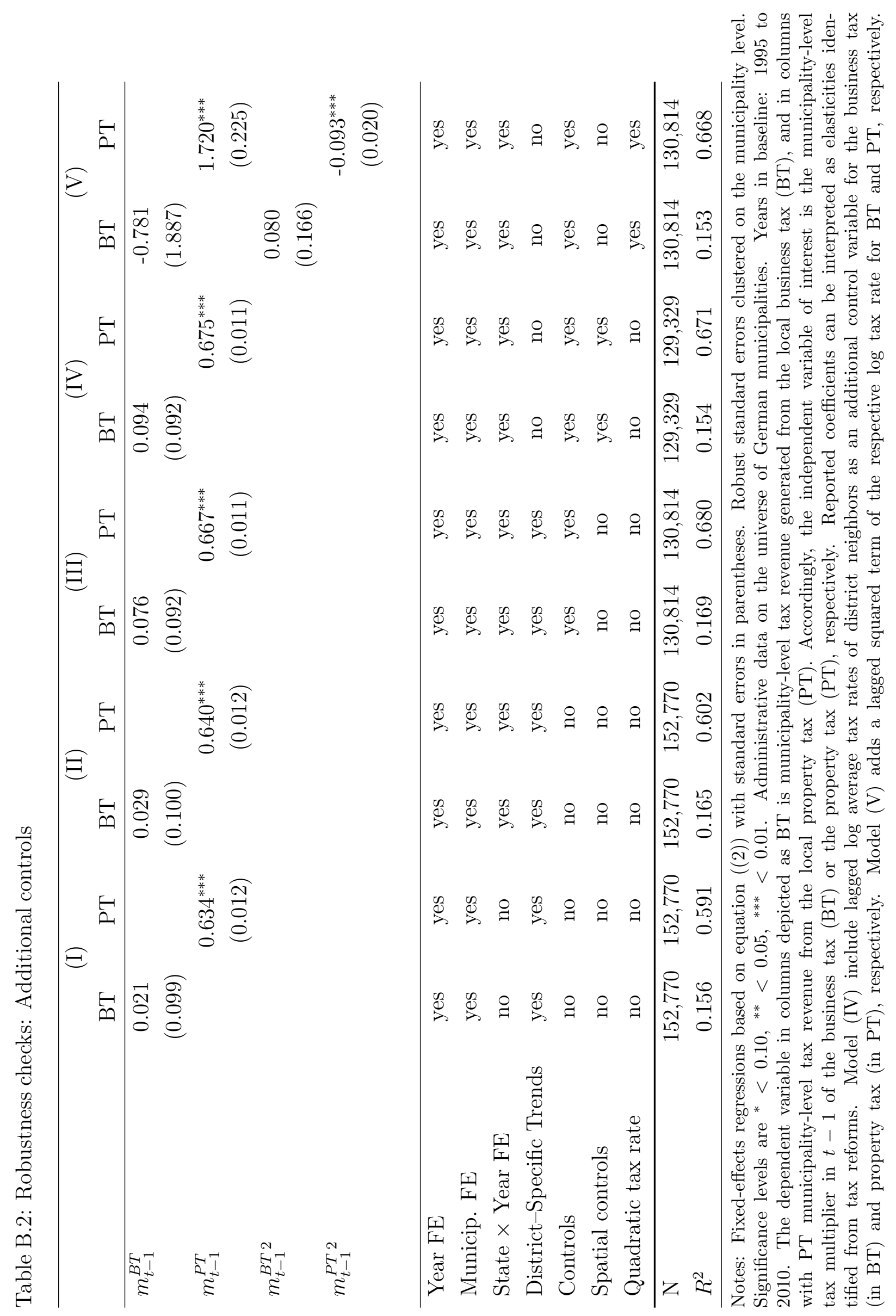




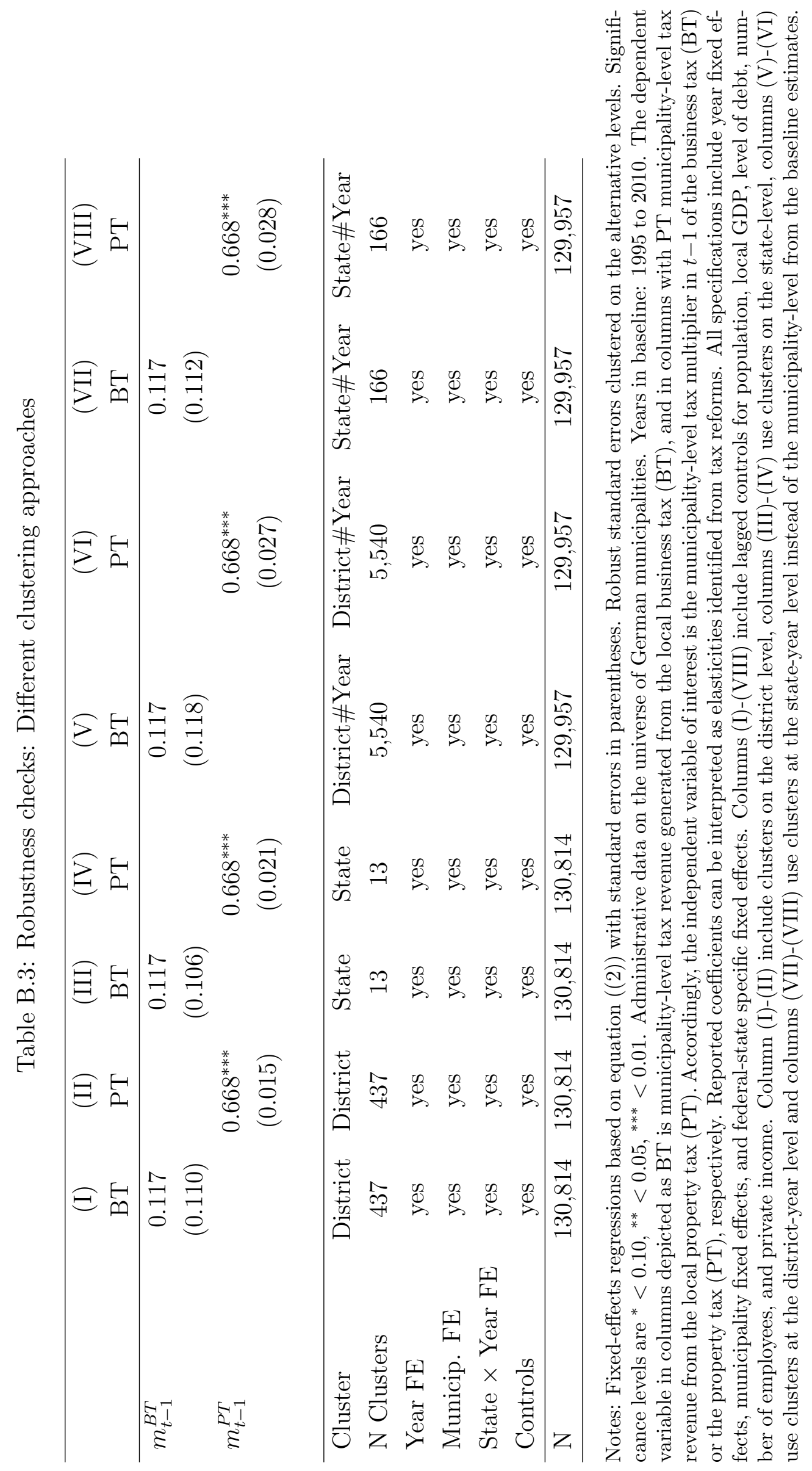




\section{Event-study results}

Table C.1: Event-study estimates: Baseline effects

\begin{tabular}{ccccccc}
\hline \multicolumn{3}{c}{ Business tax } & \multicolumn{3}{c}{ Property tax } \\
\hline & Large hike & Hike & Drop & Large hike & Hike & Drop \\
\hline F3 & -0.030 & $-0.032^{*}$ & 0.053 & 0.004 & $0.006^{* * *}$ & 0.002 \\
& $(0.034)$ & $(0.018)$ & $(0.078)$ & $(0.003)$ & $(0.002)$ & $(0.020)$ \\
F2 & 0.002 & 0.012 & -0.114 & 0.002 & 0.001 & 0.004 \\
& $(0.032)$ & $(0.015)$ & $(0.106)$ & $(0.003)$ & $(0.002)$ & $(0.021)$ \\
L0 & 0.045 & 0.017 & 0.062 & $0.112^{* * *}$ & $0.077^{* * *}$ & $-0.103^{* * *}$ \\
& $(0.031)$ & $(0.015)$ & $(0.079)$ & $(0.003)$ & $(0.002)$ & $(0.025)$ \\
L1 & 0.039 & $0.043^{* *}$ & $0.130^{*}$ & $0.115^{* * *}$ & $0.078^{* * *}$ & $-0.106^{* * *}$ \\
& $(0.034)$ & $(0.018)$ & $(0.074)$ & $(0.004)$ & $(0.002)$ & $(0.025)$ \\
L2 & $0.056^{*}$ & $0.039^{* *}$ & $0.166^{*}$ & $0.114^{* * *}$ & $0.074^{* * *}$ & $-0.138^{* * *}$ \\
& $(0.033)$ & $(0.020)$ & $(0.098)$ & $(0.005)$ & $(0.003)$ & $(0.029)$ \\
L3 & 0.021 & $0.039^{*}$ & 0.021 & $0.113^{* * *}$ & $0.071^{* * *}$ & $-0.134^{* * *}$ \\
& $(0.035)$ & $(0.020)$ & $(0.093)$ & $(0.005)$ & $(0.003)$ & $(0.038)$ \\
\hline $\mathrm{N}$ & 36,217 & 36,217 & 14,910 & 37,126 & 37,126 & 10,614 \\
\hline
\end{tabular}

Notes: The table depicts the event study estimates from Figure 2. We do not show end points of the 4-4 window in this table for the following reason: We bin up event dummies at the end points of the event window. So the dummies $D_{i, t}^{j, 4}$ and $D_{i, t}^{j,-4}$ account for all events four or more years away from the event. This is necessary because reform years differ across municipalities. Because of this procedure, we do not plot the endpoint estimates in our eventstudy graphs. We also do not plot them in the respective Figure 2. Robust standard errors clustered on the municipality level. Significance levels are ${ }^{*}<0.10,{ }^{* *}<0.05,{ }^{* * *}<0.01$. 


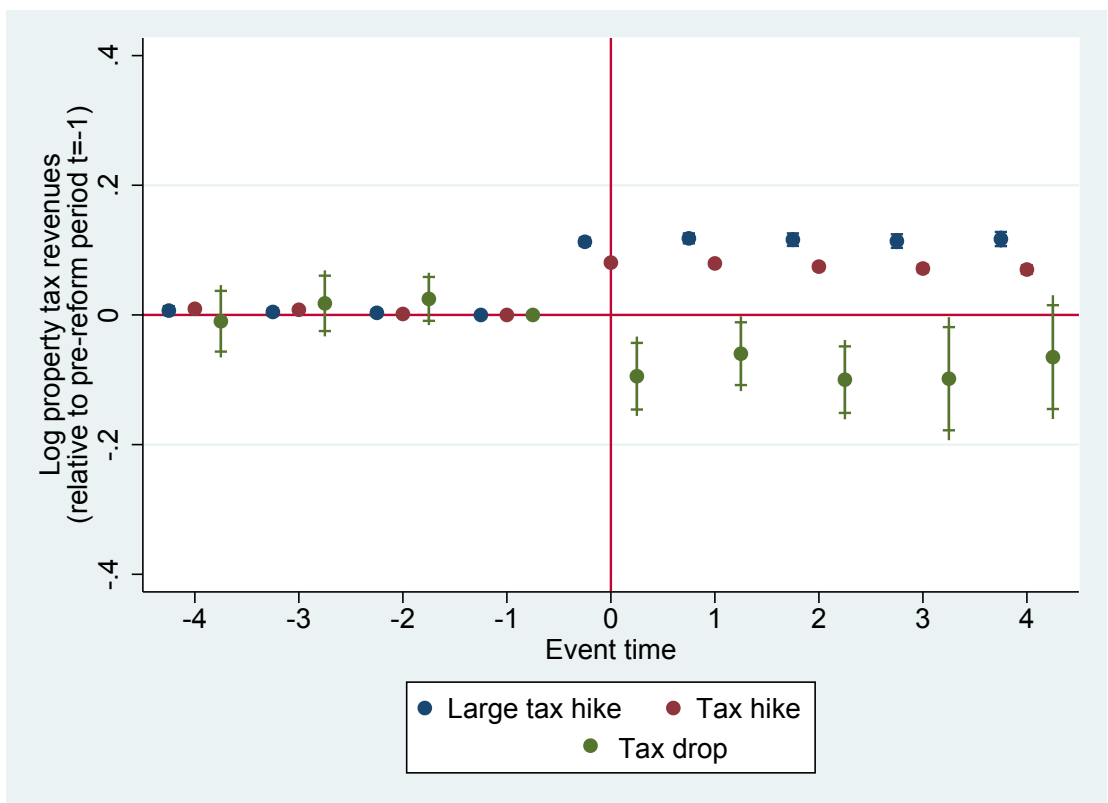

(a) Property tax

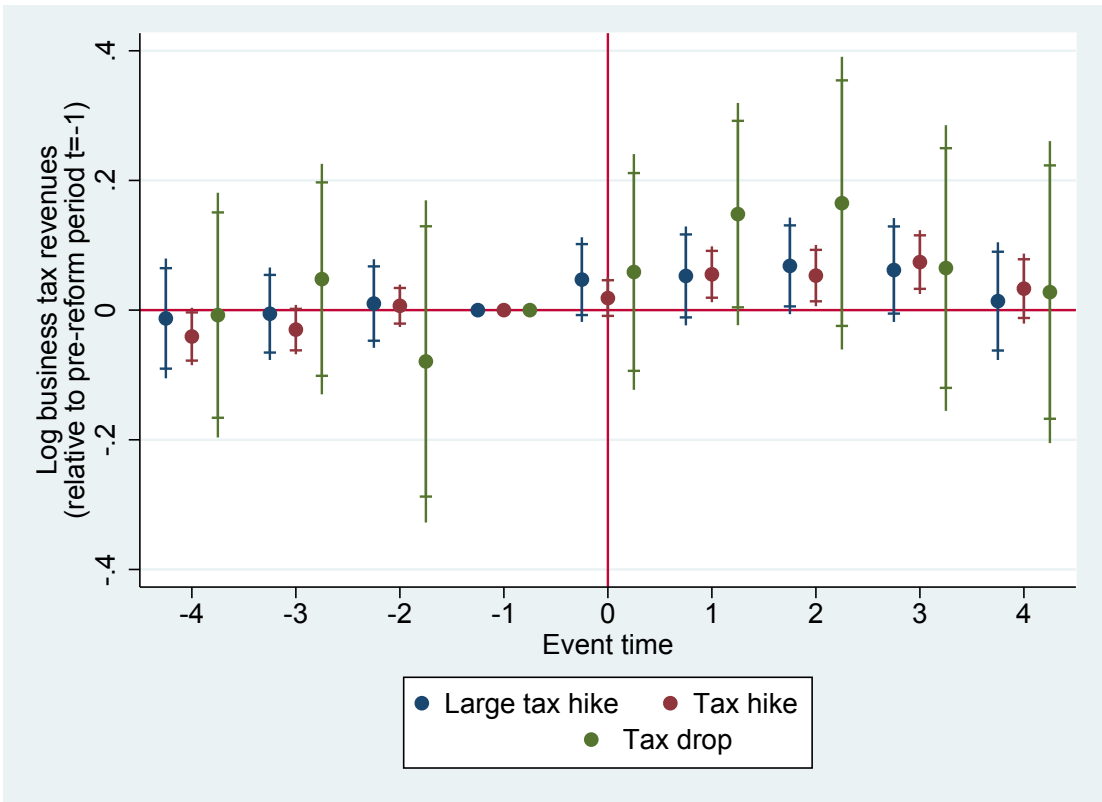

(b) Business tax

Figure C.1: Event-study graphs: Alternative event window with -5 to 5 years

Notes: Panel (a) plots event study estimates for property tax rate reforms on the log property tax revenues. Panel (b) illustrates the related findings for the business tax. Both panels show eventstudy estimates $\left(\gamma^{j} ; j \epsilon[-4 ;+4]\right)$, i.e. without window ends, for the baseline scenario of a 5 to 5 year event window and the corresponding $90 \%$ (vertical line) and 95\% confidence bands (horizontal line) for different reform types of equation 1 . Event variables are dummies equal to one for a tax increase, a large tax increase (greater than or equal to the 75 th percentile of the tax increase distribution), or a tax decrease (see legend). In specifications with tax increase (decrease) dummies, we exclude all municipalities that experienced a tax decrease (increase) during the observation period. We also balance our event-study such that only tax reforms are included that are observed throughout the whole event window, here 5 years before and after the reform. 


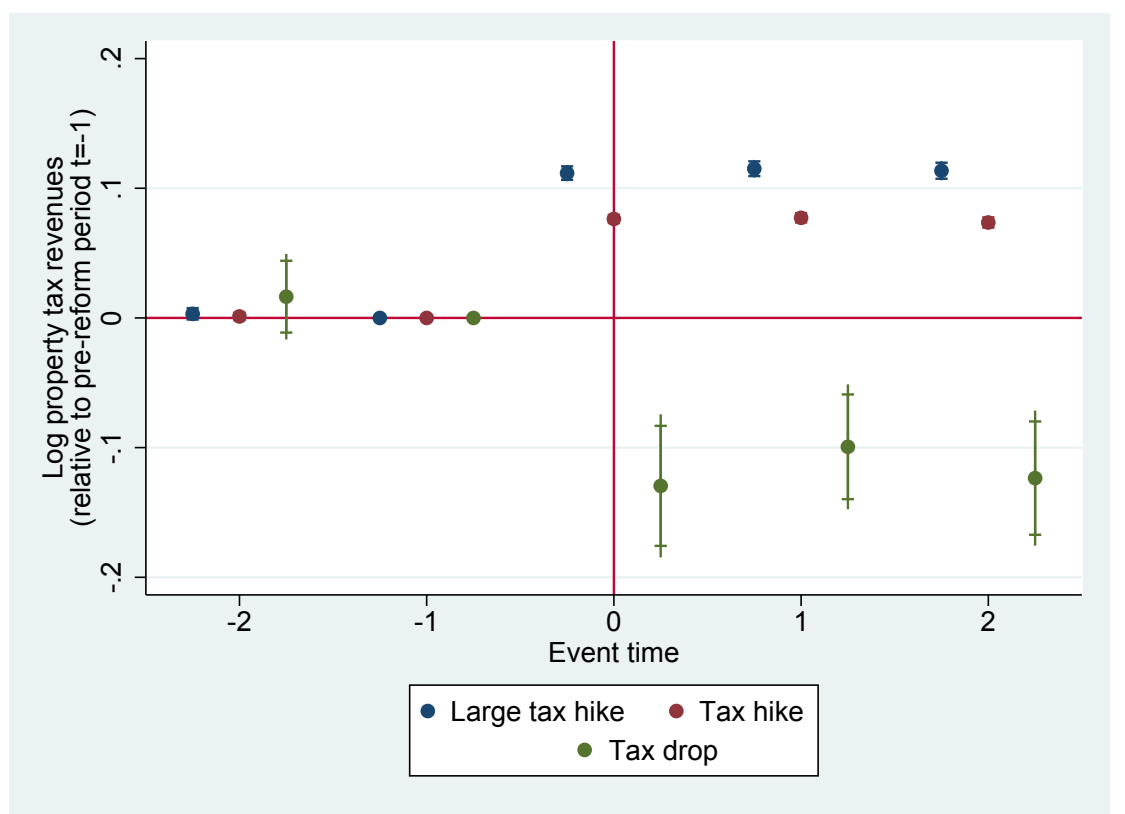

(a) Property tax

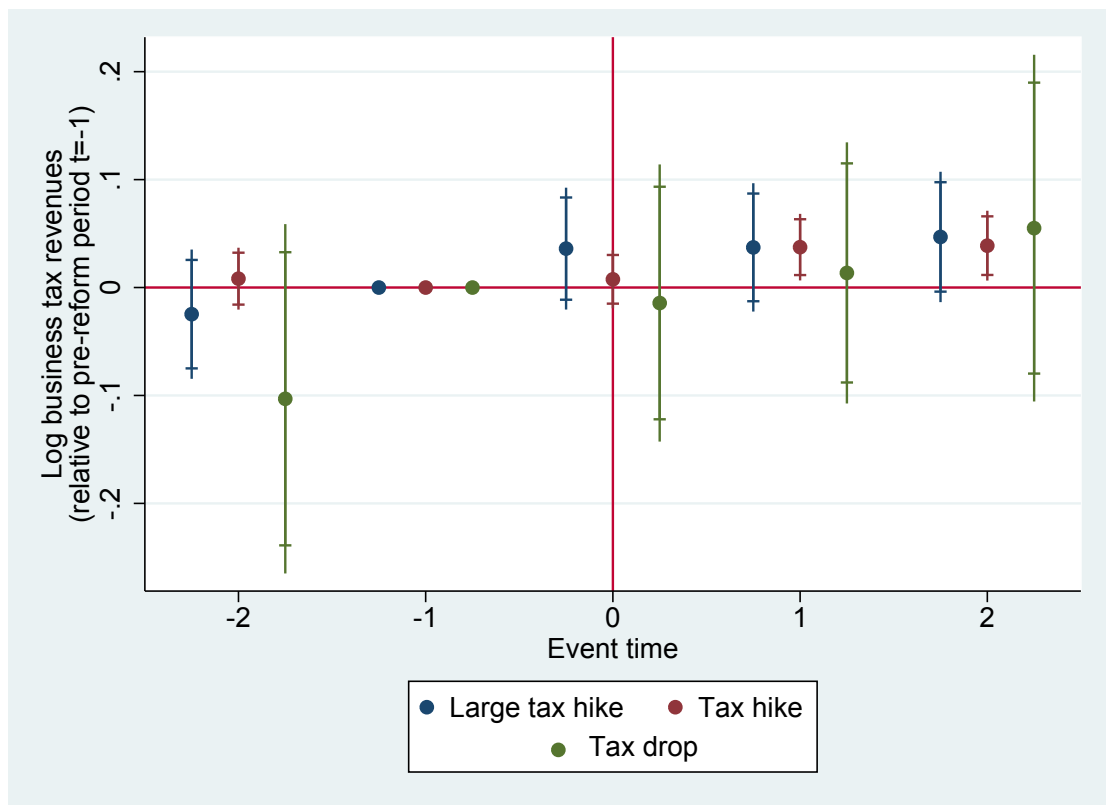

(b) Business tax

Figure C.2: Event-study graphs: Alternative event window with -3 to 3 years

Notes: Panel (a) plots event study estimates for property tax rate reforms on the log property tax revenues. Panel (b) illustrates the related findings for the business tax. Both panels show eventstudy estimates $\left(\gamma^{j} ; j \epsilon[-2 ;+2]\right)$, i.e. without window ends, for the baseline scenario of a 3 to 3 year event window and the corresponding $90 \%$ (vertical line) and $95 \%$ confidence bands (horizontal line) for different reform types of equation 1 . Event variables are dummies equal to one for a tax increase, a large tax increase (greater than or equal to the 75th percentile of the tax increase distribution), or a tax decrease (see legend). In specifications with tax increase (decrease) dummies, we exclude all municipalities that experienced a tax decrease (increase) during the observation period. We also balance our event-study such that only tax reforms are included that are observed throughout the whole event window, here 3 years before and after the reform. 